Portland State University

PDXScholar

\title{
Western Juniper (Juniperus occidentalis) Ecology with an Exercise in Remote Sensing Techniques
}

\author{
Elizabeth A. Goralski \\ Portland State University
}

Follow this and additional works at: https://pdxscholar.library.pdx.edu/geog_masterpapers

Part of the Nature and Society Relations Commons, Physical and Environmental Geography Commons, and the Remote Sensing Commons Let us know how access to this document benefits you.

\section{Recommended Citation}

Goralski, Elizabeth A., "Western Juniper (Juniperus occidentalis) Ecology with an Exercise in Remote Sensing Techniques" (2008). Geography Masters Research Papers. 11.

https://pdxscholar.library.pdx.edu/geog_masterpapers/11

10.15760/geogmaster.11

This Paper is brought to you for free and open access. It has been accepted for inclusion in Geography Masters Research Papers by an authorized administrator of PDXScholar. Please contact us if we can make this document more accessible: pdxscholar@pdx.edu. 
Western Juniper (Juniperus occidentalis) Ecology with an Exercise in Remote Sensing Techniques

Elizabeth A. Goralski

Submitted for partial fulfillment of Master of Science degree in Geography Portland State University

Approved by:

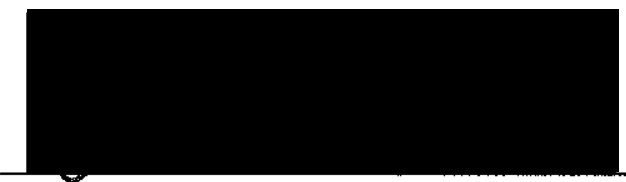

Jiunn-Der Duh, Assistant Professor

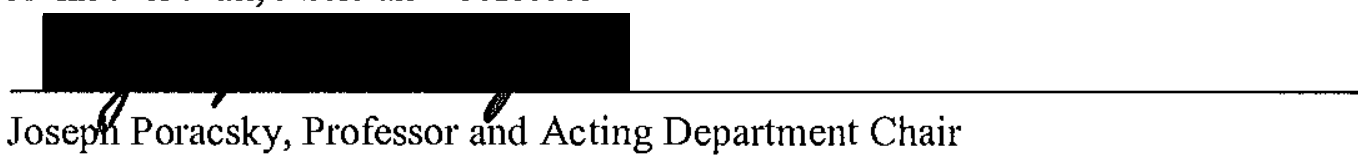

Date:

28 Angust 2008 
Western Juniper (Juniperus occidentalis) Ecology with an Exercise in Remote

Sensing Techniques

August 25, 2008

Elizabeth Goralski

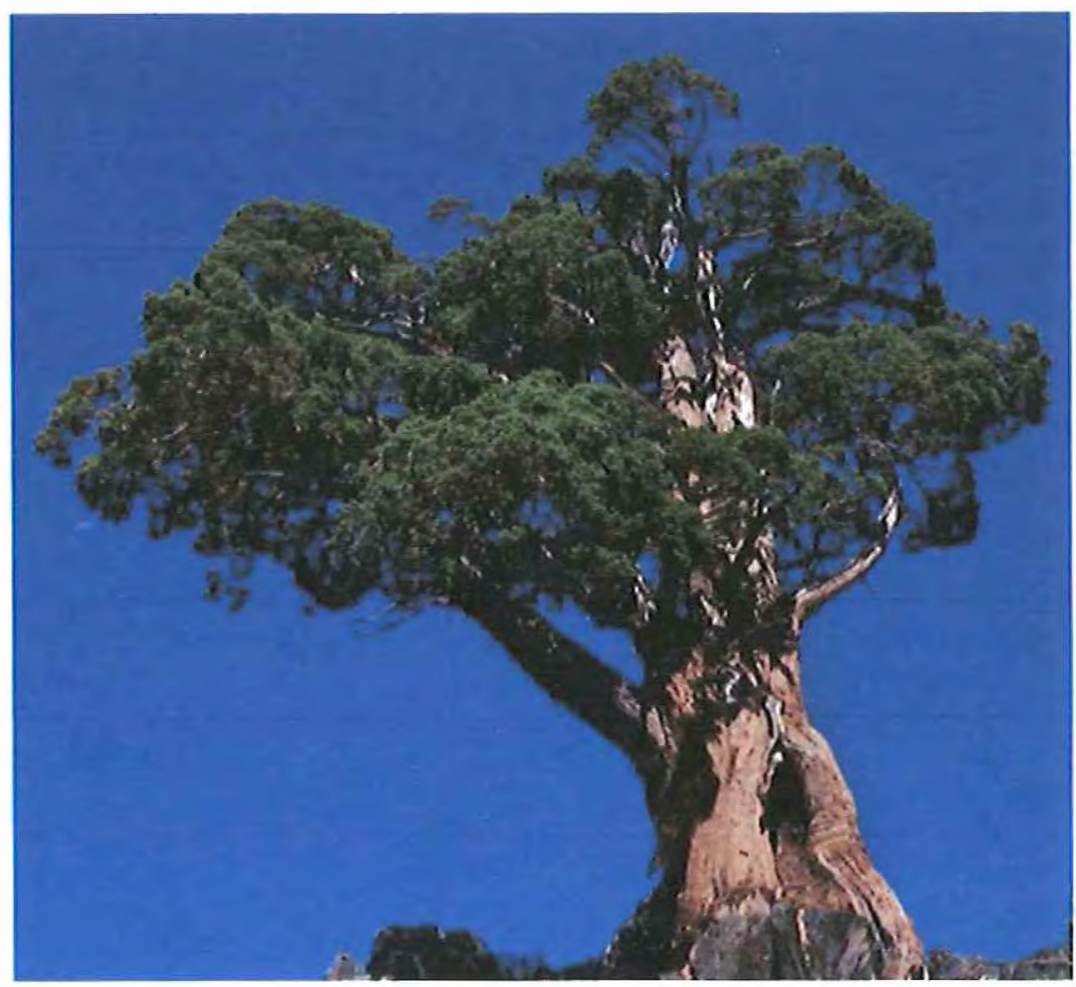


Western Juniper (Juniperus occidentalis) Ecology with an Exercise in Remote

Sensing Techniques

August 25, 2008

Elizabeth Goralski

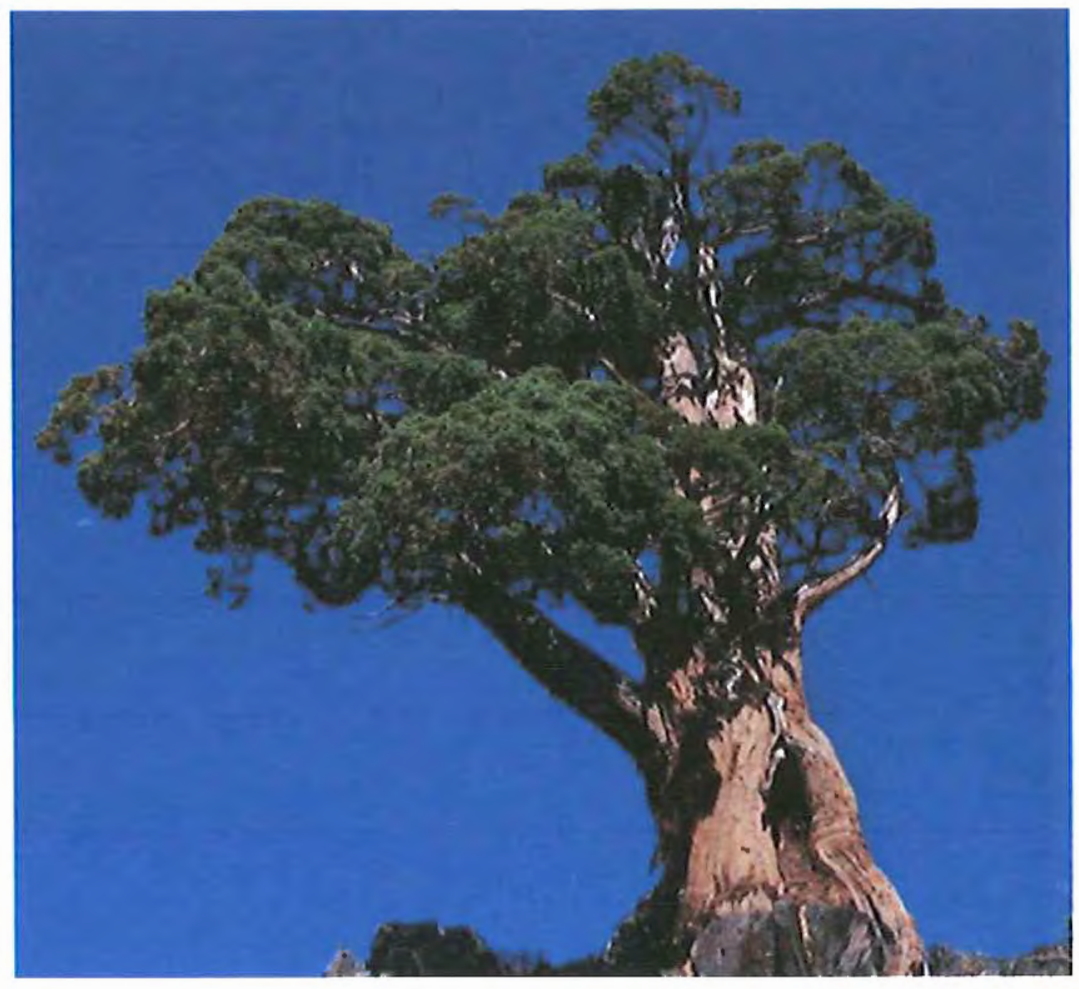




\title{
Western Juniper (Juniperus occidentalis) Ecology with an Exercise in Remote
}

\author{
Sensing Techniques
}

\begin{abstract}
Western juniper (Jumiperus occidentalis var. occidentalis) has been expanding its biogeographic range since the mid-1800's, resulting in decreased biodiversity, altered wildlife habitat, increased soil erosion, reduced stream flows and reduced forage production. The direct causes of western juniper aforestation are unclear but appear to be related to altered fire regimes, over grazing, and climatic shifts.

This study seeks to determine how Landsat images combined with Digital Orthoquads (DOQs) can be used to examine the geographic distribution of western juniper. Satellite inagery has yet to be applied to the large scale mapping of western juniper aforestation, resulting in the lack of regional and landscape level monitoring of western juniper range expansion. Remote sensing technologies, when combined with geographical information systems provide potentially valuable tools for monitoring western juniper expansion because of their abilities to assess large scale coverage of scenes, high cost effectiveness, and minimal field crew requirements. The two main objectives of my research are to review and summarize current literature regarding western juniper expansion and explore how remote sensing techniques may be used to quantify the expansion of the species. The results of my studies suggest that large patches of western juniper are detectable using Landsat imagery.
\end{abstract}




\section{TABLE OF CONTENTS}

I. INTRODUCTION

II. STUDY AREA

III. WESTERN JUNIPER ECOLOGY

A. DISTRIBUTION AND CHARACTERISTICS

IV. LITERATURE REVIEW

A. WESTERN JUNIPER

V. REMOTE SENSING METHODS

A. IMAGERY

B. FIELD OBSERVATIONS

C. IMAGE CLASSIFICATION

D. SUPERVISED CLASSIFICATION

E. ACCURACY ASSESSMENT

VI. RESULTS

VII. CONCLUSIONS

VIII. REFERENCES 


\section{INTRODUCTION}

Western juniper (Juniperus occidentalis var: occidentalis) has been expanding its range since the 1800 's (e.g. Miller and Rose 1995, Soulé et al. 2004). Based on estimates made by Azuma et al. (2005), western juniper's biogeographic range in Oregon increased from 1.5 million acres in the 1930's to over 6 million acres in 2005 . This change has contributed to decreases in biodiversity, altered wildlife habitat, increased soil erosion, reduced stream flows and reduced forage production (Miller et al. 2005). The cause of western juniper aforestation is unclear (Soulé and Knapp 1999, Miller and Rose 1999) but appear to be related to altered fire regimes, over grazing, and climatic shifts (Burkhardt and Tisdale 1976, Knapp and Soulé 1998 and Miller and Rose 1995).

Previous studies indicate that aerial photography can be used to locally monitor juniper aforestation (Soulé and Knapp 2000) but satellite imagery has yet to be applied to

the large $\left(>25 \mathrm{mi}^{2}\right)$ scale mapping of western juniper aforestation. This has resulted in a lack of regional and landscape scale monitoring of western juniper. Using Landsat to monitor western juniper would provide a means to rapidly assess the rate and extent of aforestation because of the area covered in Landsat scenes, the relative ease of image acquisition, and approximately 35 -year image record.

This paper explores the potential application of Landsat Enhanced Thematic Mapper (ETM) to monitor the biogeographic expansion of western juniper in central Oregon. My goal is to determine the ability of Landsat TM to delineate western juniper land cover relative to adjacent ponderosa pine (Pims Ponderosa) forests and sagebrushsteppe. I assess this potential by comparing image classification results with the presence 
of vegetation types identified on the ground using GPS coordinates and through the visual interpretation of digital orthoquads.

My paper is organized in the following fashion: I begin with a description of the study area, followed by a literature review of the ecology of western juniper and remote sensing methods used to map shrubs. I then describe my remote sensing methods and results and end with my conclusions and suggestions for future studies.

\section{STUDY AREA}

The study area covering ca. $150,000 \mathrm{~km}^{2}$ is located near the boundary between Lake, Deschutes, Crook, and Harney Counties in Central Oregon (Figure 1). The western boarder of the study area includes the eastern portion of the Fremont/Deschutes National Forest. The study area includes two geologic landmarks, Fort Rock State Monument and Hole in the Ground Scenic Area. The study area skirts the south eastern corner of Bend north to the Maury Mountains in the Ochoco National Forest. The eastern boarder of the study area is the Malheur National Wildlife Refuge. Warner Valley, Lake Albert and Summer Lake provide the natural boundary to the south. 


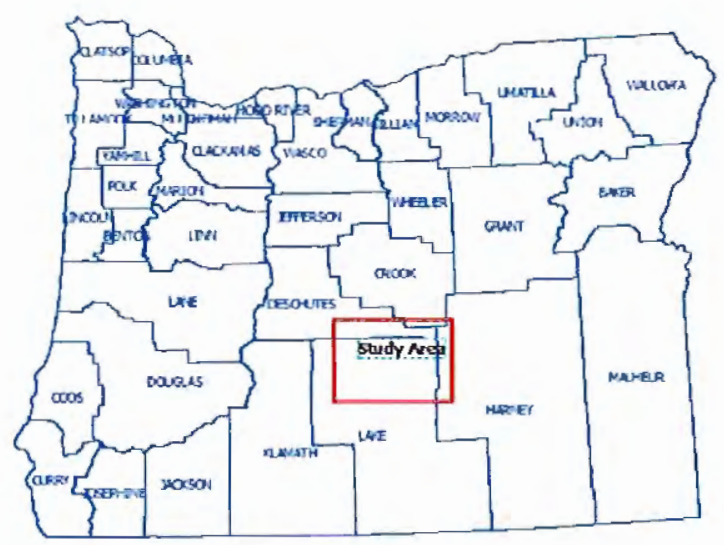

Figure 1. Location of study area in central Oregon.

The study area consists of 3 major ecoregions (Omerick, 1987): Pumice Plateau, High Lava Plains, and Pluvial Lake Basin. Elevation ranges from $1310 \mathrm{~m}$ in the valleys to $2070 \mathrm{~m}$ in the Fremont National Forest. Local bedrock is weathered basalt interlaced with lava flows and Quaternary sedimentary deposits. Local soil textures are primarily ashy loamy sand derived from eolian sand and pumice derived from volcanic eruptions of Mt. Mazama and Newberry Crater. Sand dunes and alkali flats dot the landscape. The sand dunes are composed largely of ash and pumice from the Mt. Mazama eruption approximately 7,000 years before present that formed Crater Lake.

The study area contains a mix of private and public lands managed primarily by the US Forest Service (USFS) and U.S. Bureau of Land Management (BLM). Landuse primarily consists of grazing and irrigated agriculture. 


\section{WESTERN JUNIPER ECOLOGY}

\section{Distribution and Characteristics}

Western juniper habitat ranges from northern California to the Columbia River, and eastward from the foothills of the Cascades to the western boarder of Idaho. In Oregon, juniper presently covers more than 6 million acres (Azuma et al. 2005). Juniper is the most xeric of forest types in Oregon occupying the transition zones between grassland-sagebrush (Artemisia tridentata) steppe and ponderosa pine (Pinus ponderosa) forests (Franklin and Dyrness 1973). Western juniper is found at elevations ranging from 305 to 2,500 meters with $95.5 \%$ of juniper forests and savannas occurring from 610 to 2,000 meters (Gedney et al. 1999). Areas below 305 meters are often used for agriculture and above 2,200 meters extremes in weather conditions and frost limit juniper growth (Miller and Rose 1995). Juniper forests are considered to have 10\% stocking rate or crown cover as defined by the National Forest Inventory and Analysis (FIA) (http://fia.fs.fed.us/library/fact-sheets/). Areas with less than $10 \%$ juniper cover are considered savannas. The highest density of western juniper occurs near the John Day region in Oregon (Gedney et al. 1999) but it can be found extensively throughout eastcentral Oregon.

Western juniper trees are pyramidal to round in shape and typically reach 4-19 m in height at maturity, but will occasionally reach $19.8 \mathrm{~m}$ in height. Trunks are usually composed of a single erect stem 34.8-70.1 cm diameter (maximum of $190 \mathrm{~cm}$ ) (Vasek 
1966; Cronquist et al. 1972). Mature western juniper leaves are compressed to the stem and overlapping the next leaf. Leaves occur as opposite pairs or in whorls of three. In contrast, juvenile leaves are not compressed to the stem and are spiny tipped. Seed bearing can begin as early as 10-20 years of age but significant fruit production usually starts at 50-70 years of age (Miller and Rose 1995). Male cones develop during the late summer and early fall and shed their pollen early the following spring (Vasek 1966).

Artemesia tridentata (Basin Big Sagebrush) is a common associate of western juniper. Sagebrush are evergreen shrubs ranging in size from less than $0.6 \mathrm{~m}(2 \mathrm{ft})$ tall to as large as $4 \mathrm{~m}(13 \mathrm{ft})$ tall. Branches are spreading, arising from numerous main stems in the lower growing subspecies or form one main trunk in the larger forms. Leaves are blue-gray to blue-green in color due to dense gray hairs. The gray-green leaves are not fall conspicuous. The green flowers usually bloom in the late summer.

\section{LITERATURE REVIEW}

\section{Western Juniper}

The ecological impacts of western juniper expansion are diverse and complex. Although pre-settlement woodlands of J. occidentalis were confined to rocky areas and ridges (Miller and Rose, 1995), the current landscape composition comprises old multistory juniper (18\%), young-multi-story juniper (16\%), and open young or stand initiation juniper (66\%) (Roth 2004). The strongest evidence for the post-settlement expansion of western juniper is from tree-ring chronologies. These chronologies, which describe the 
age composition and establishment woodlands over time, show a rapid increase in establishment since the 1870's (Miller and Tausch, 2001; Soulé et al. 2004).

Miller et al. (2000) demonstrate how mountain big sagebrush (Artemisia

tridentata yar. tridentata) and aspen (Populus tremuloides) decline as juniper stands increase in cover in Oregon and the Great Basin. Three-fourths of sampled aspen stands in Oregon and the Great Basin show juniper establishment (Wall et al. 2001).

The replacement of aspen and big sagebrush may have detrimental effects on wildlife. Depending upon successional stage, juniper stands can vary in composition. Old-growth stands differ structurally from post-settlement woodlands, including having a greater density of cavities, which may influence nesting species (Waichler et al. 2001). Juniper has low nutritional value for large herbivores and is only browsed in the winter if little else is available (Adams 1975).

Increased soil erosion is associated with expanding juniper forests. Rainfall effects on hill slopes in rangelands in the western U.S. and the subsequent hydrologic response involves a complex vegetation-soil interaction (Pierson et al. 2002). Wood (1988), found that pattern and density of vegetation cover alters soil properties. Higher plant density, cover and dispersion offer better soil protection from erosion (Blackburn et al. 1994). Juniper forests have less understory vegetation and thus may have greater soil erosion potential (Miller et al. 2000). Petersen and Stringham (2008) used a small plot rainfall simulator to measure the infiltration rate, runoff, and sediment content in a western juniper watershed. Their findings suggest that less water is available to sustain understory and inter-canopy plant growth in areas with high juniper cover and that 
accelerated runoff and erosion in juniper dominated sites can lead to excessive degradation to the hydrology of those sites.

Roberts and Jones (2000) compared the sizes, spacing and soil properties of resource islands and bare patches in sagebrush-grass communities invaded by western juniper versus those without juniper. The study area was at the southern edge of Lake Billy Chinook in the Palisades State Park in Central Oregon. The presence of juniper was associated with increased bare soil and smaller, more widely spaced grass and sagebrush plants. Soil arthropod numbers and biomass in plots with juniper were roughly one-fifth of those in sagebrush-grass plots.

Numerous studies have analyzed the causes of western juniper expansion with no unifying conclusion. Several theories attempt to explain the expansion such as altered fire regimes, livestock grazing and increased levels of $\mathrm{CO}_{2}$. Soulé et al. (2004) used dendroecological techniques to investigate four sites (two disturbed and two undisturbed) to determine how livestock grazing and fire affect juniper establishment. This study found that disturbance induces aforestation, but the undisturbed sites also experienced juniper regeneration and growth. Soulé et al. (2004) suggest that climatic factors such as an increase in $\mathrm{CO}_{2}$ may be yet another reason for the expansion.

In 2001, Knapp, Soulé and Grissino-Mayer examined atmospheric $\mathrm{CO}_{2}$ fertilization on radial growth rates and concluded that there is a possible correlation between drought, increases in $\mathrm{CO}_{2}$, and radial growth rates in juniper. This suggests that juniper is better suited for tolerating drought and increased carbon dioxide.

Miller and Rose (1999) examined fire return histories, weather conditions, and livestock records in south-central Oregon. Their study shows climate, reduced fire 
intervals, and livestock grazing contributed to the post-settlement expansion of western juniper. Johnson and Miller (2006) suggest that topography and elevation are also contributing variables influencing woodland expansion.

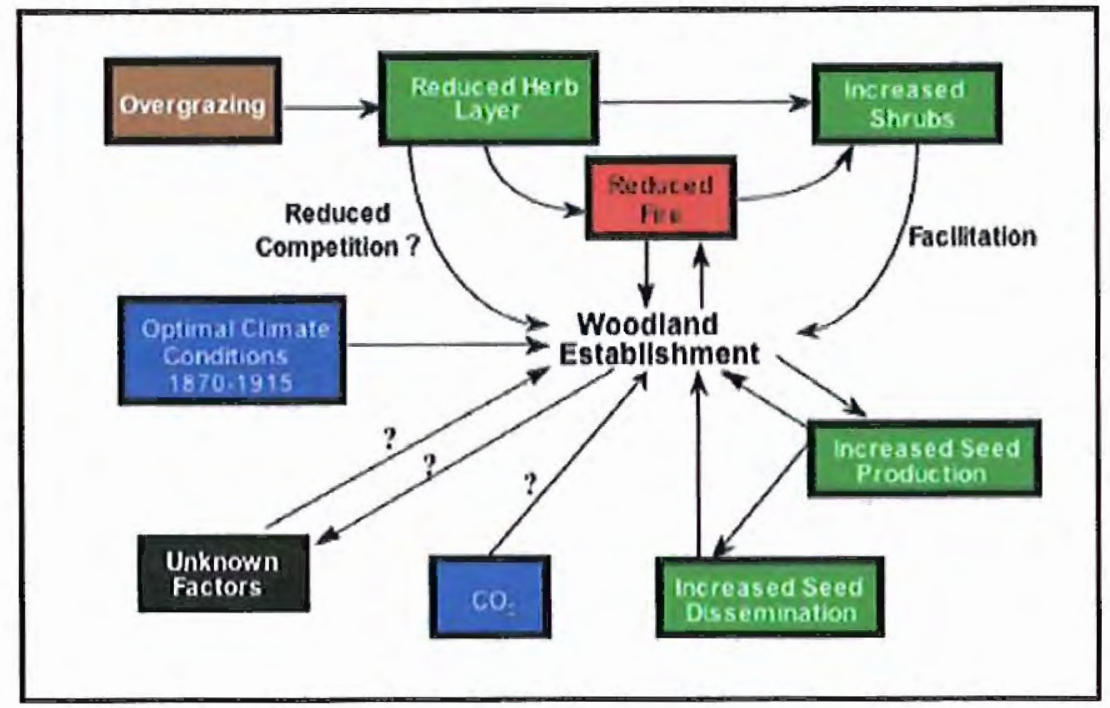

Figure 2. A conceptual model illustrating the factors influencing the expansion of western juniper since the late 1800's to the present (Miller and Tausch 2001).

Analysis of the spatial patterns of woody plants is an important approach to understanding the ecological processes that direct the expansion of western juniper on the landscape. Strand et al. (2007) used Ripley's K-functions and the pair-correlation function $g$ to analyze the second order characteristics of a marked spatial point pattern of western juniper. The marked point process of crown diameters was created using a twodimensional wavelet analysis of fine scale aerial photography. Strand et al. (2007) identified two statistically significant spatial scale characteristics of J. occidentalis on the woodland/steppe ecotone: (1) They observed inhibition between J. occidentalis plants at distances $<15 \mathrm{~m}$, results in a regular pattern, rather than clumped or random and (2) $J$. occidentalis at the ecotone scale exhibits significant clustering with a $30-60$ m radius. 
The spatial distribution of western juniper (on small scales $<100 \mathrm{~m}$ ) can be attributed to the territory size of berry-eating birds and the nutritional requirements of older,

established trees. At larger scales, juniper trees are randomly distributed suggesting that additional long-range seed dispersal processes are at work.

Aerial photography is the most common form of remote sensing imagery used in quantifying western juniper expansion. Using aerial photography at a scale of $1: 19,900$ and 1:12,000, Soulé and Knapp (1999) quantified juniper aforestation on several study sites. When using aerial photography on a scale of $1: 31,680$, juniper seedlings and saplings could not be distinguished (Gedney et al. 1999). While this may be a problem for medium resolution satellite imagery, the overall trends of afforestation should be apparent. Many land use land cover mapping techniques have been applied to other forest types. These methods will be applied to the satellite images and are discussed in the Remote Sensing Methods section of this paper.

\section{REMOTE SENSING METHODS}

\section{Imagery}

My research used Landsat ETM satellite imagery for September 18, 1999. The image obtained through the Global Observatory of Ecosystems Services (GOES) at Michigan State University. These orthorectified, public domain datasets are available via FTP from the website http://Landsat.org. I also used 2005 half-meter digital 
orthoimagery quadrangles (DOQs) acquired through the National Agriculture Imagery Program (NAIP) as ground truth data. The Oregon Imagery Explorer web mapping service (http://oregonexplorer.info/imagery/) provides access to these aerial images.

The GOES Landsat images include a limited number of rectified images available for no cost. This data source does not allow user specification of the date and sensor but allows the path and row to be selected by the user. I chose the path/row combination of $44 / 30$ because this scene covers a large portion of central Oregon lacking previous studies of western juniper afforestation.

I used Digital Elevation Models (DEMs) to visually assess the relation between juniper distribution, elevation, slope, and aspect. These DEMs are available at 10 and 80 meter resolution for the state of Oregon. These images are available to students enrolled at Portland State University.

Google Earth is also a useful source for imagery. I used Google Earth for initial interpretation of the study area. Not all areas of the study area were linked to high resolution images but Google Earth was useful for accuracy assessment reference data.

\section{Field Observations}

During the week of April 18-20, 2008, I visited my study area to gain a better understanding of the landscape. Because of the large size of the study area I collected my field data in Christmas Valley near Hole in the Ground Scenic Area and the Devils Garden Lava Outcrop. I collected 43 data points to serve as accurate ground control data points using a Trimble GeoXM datalogger supported by Microsoft Windows Mobile 
Version 5.0 software. In addition to $\mathrm{x}, \mathrm{y}$ coordinates, I recorded general species composition and any other unique features of the area. My sample reference points were collected at random distances along primitive roads crossing juniper woodlands, savannas, ponderosa forests, and sagebrush communities. Figure 3 depicts the 43 GPS datalogged points.

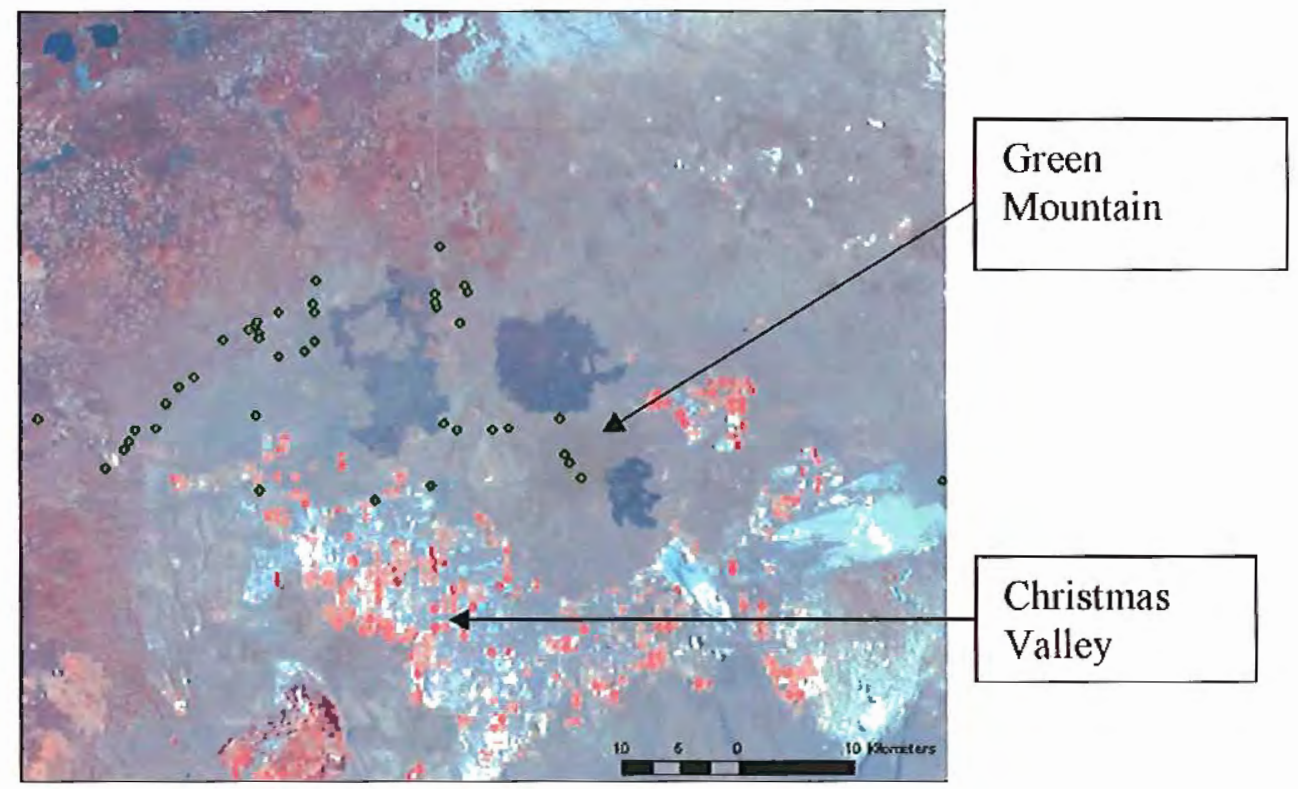

Figure 3. Location of 43 GPS Points in Christmas Valley, OR.

\section{Image Classification}

Image classification is a procedure used in most remote sensing studies. This process consists of two stages. The first stage is the recognition of categories of real world objects. The second stage is labeling pixels so they can be classified (Mather 
2004). There are also two different means to label pixels, unsupervised and supervised classification.

I began my analysis of the Landsat image using an unsupervised classification. Unsupervised classification provides "comprehensive information on the spectral characteristics of an area, offers spectrally pure clusters for labeling and allows for the grouping of similar clusters by the analyst" (Jiang et al. 2004). ERDAS Inagine uses the ISODATA algorithm in unsupervised classification. The ISODATA (Iterative SelfOrganizing Data Analysis Technique) clustering method uses the minimum spectral distance formula to form clusters. It begins with either arbitrary cluster means or means of an existing signature set. Each time the clustering repeats, the means of these clusters are shifted. The new cluster means are used for the next iteration. The ISODATA utility repeats the clustering of the image until either a maximum number of iterations have been performed, or a maximum percentage of unchanged pixel assignments have been reached between two iterations. Performing an unsupervised classification is simpler than a supervised classification because the signatures are automatically generated by the ISODATA algorithm (ERDAS Field Guide, 2005).

The user can specify how many spectral classes to create using unsupervised classification. I ran four separate trials using $20,40,60$, and 90 classes with 20 iterations each. Examining one class at a time, I determined if each class was "juniper" or "not juniper" by switching back and forth between the satellite image and the DOQs from the Oregon Imagery Explorer. For those classes not representing juniper, I labeled the class in another column based on my recognition of that feature on the DOQ, e.g., water, agriculture, and sand (Figure 6b). While there is a certain amount of error when looking 
at one screen and comparing it to another screen, this procedure allows a rapid identification of many cover types.

Following unsupervised classification each pixel had been assigned a class. Spectral classes of the same category were regrouped into landcover classes (Table 1). The Human Disturbance category includes agriculture and clearcut in forests. The 'juniper' category includes juniper and sage mixes while the 'other' category includes barren areas, grass, and dunes.

Table 1. Six land cover categories used in unsupervised classification.

\begin{tabular}{||c|c|}
\hline RECODE VALUE & LAND COVER LABEL \\
\hline 1 & Forest \\
\hline 2 & Human Disturbance \\
\hline 3 & Juniper \\
\hline 4 & Pipo/Juniper \\
\hline 5 & Sage, Low Veg., Grass \\
\hline 6 & Sand \\
\hline
\end{tabular}

\section{Supervised Classification}

Supervised classification, unlike unsupervised classification, requires prior knowledge of the image. Prior knowledge consists of field work, air photo interpretation, reports or other maps (Mather 2004). The 43 GPS data points collected in the field were used as training sites for supervised classification along with 34 additional training points that were selected with reference to DOQs (Figure 4). A total of 77 training sites were created. Some of the visited stands included a mix of ponderosa pine and western juniper. After recoding the supervised classes, I felt that it was important to keep the 
mixed canopy pixels separate from stands of pure pine or juniper even though the inclusion of 'mixels' or a class of mixed ponderosa/juniper may have lead to poor results in accuracy assessment. Land cover classes for supervised classification were regrouped into the same six classes used in unsupervised classification (Table 2).

Table 2. Recoded Values for the Supervised Land Use Land Cover Map

\begin{tabular}{||c|c||}
\hline RECODE VALUE & LAND COVER LABEL \\
\hline 1 & Forest \\
\hline 2 & Human Disturbance \\
\hline 3 & Juniper \\
\hline 4 & Sand \\
\hline 5 & Sage, Low Veg., Grass \\
\hline 6 & Pipo/Juniper \\
\hline
\end{tabular}

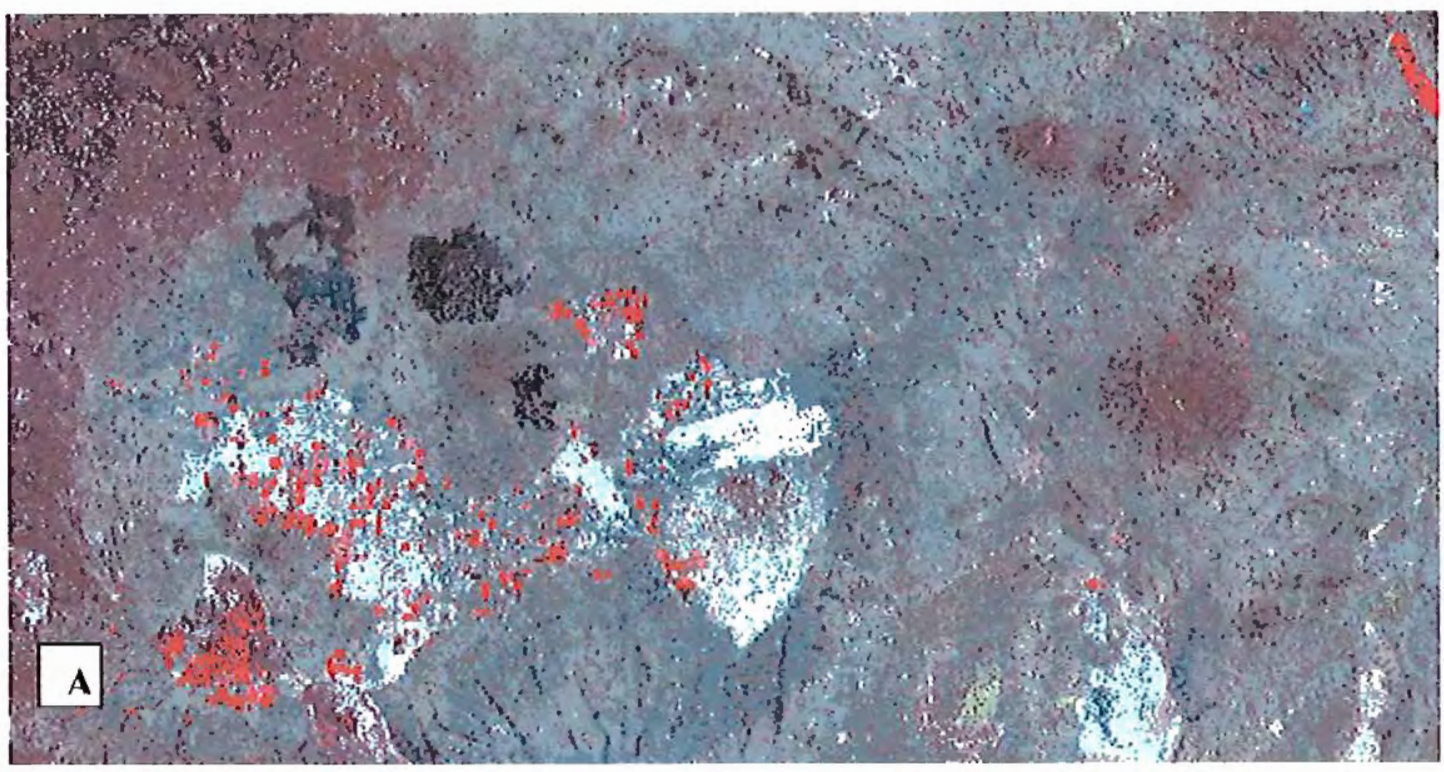




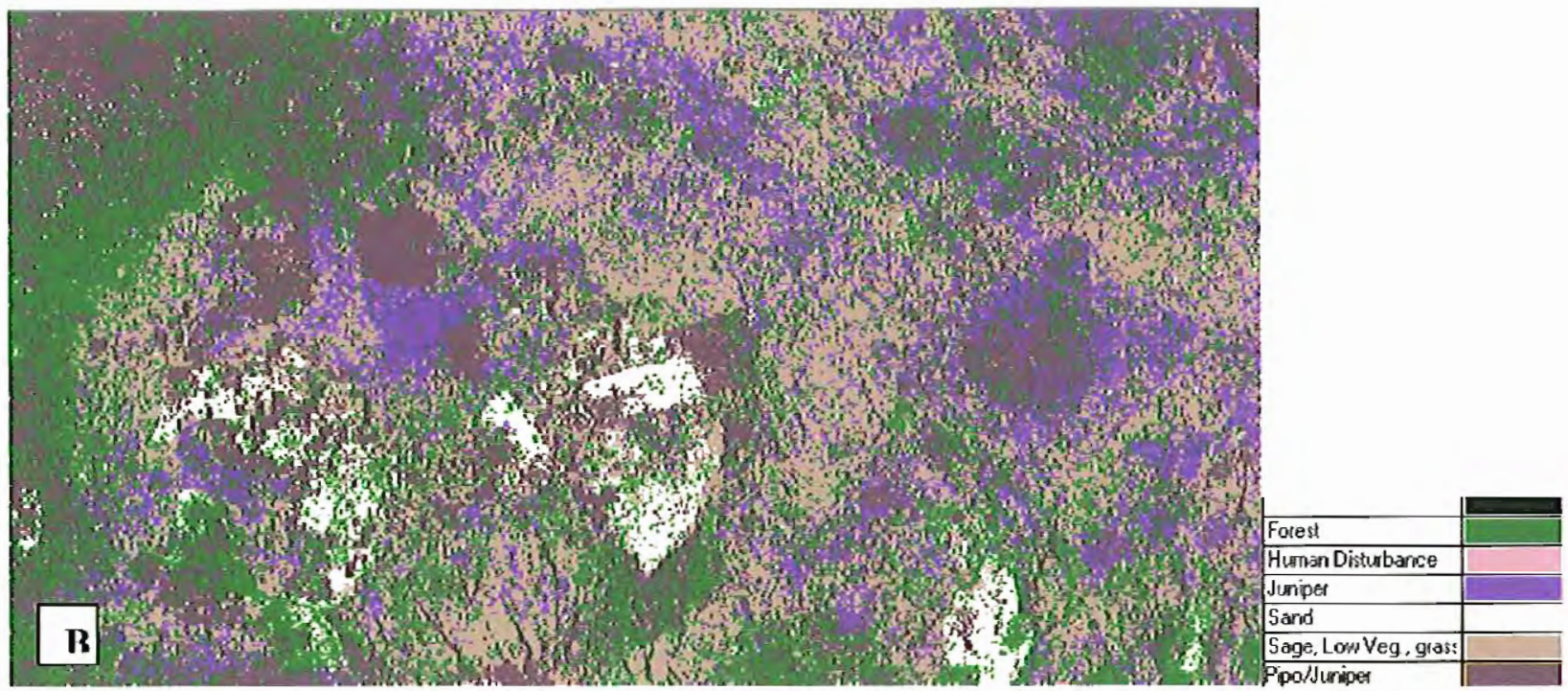

Figure 4. Initial supervised classification results using the GPS collected data points for training points as depicted in $\mathbf{A}$. The color scheme is based on the 74 training sited used. B shows the recoded supervised image using six land cover classes.

\section{Accuracy Assessment}

I completed an accuracy assessment to analyze the error of the classified landcover maps. The conventional method of representing the degree of accuracy is to build a $k x k$ confusion (or error) matrix (Mather 2004). Kappa (Bishop et al. 1975) is a statistical measurement of the information in the error matrix. I calculated Kappa to investigate the agreement of the classifier output and reference data. Fifty random points were generated for accuracy assessment. The reference data was interpreted using Digital Orthoquads. 


\section{RESULTS}

Landsat imagery alone appears to be inadequate for monitoring western juniper aforestation at the individual tree scale. Preliminary visual interpretation showed that juniper was visibly distinguishable from sagebrush and other forest types but these early results may have been erroneous. Areas that were initially classified as juniper were subsequently determined to be ponderosa pine and vice versa from field observations.

Four classified maps with different numbers of spectral classes were produced using unsupervised classification. As the number of classes increased, it appeared that the level of detail mapped increased. However, as the number of classes increased, there was also an increase in the number of pixels that were classified incorrectly. Lava flows and juniper stands were often incorrectly classified as forest. The overall accuracy for unsupervised classification yielded mediocre results with an overall accuracy of $64 \%$ with a Kappa $=0.5464$.

Table 3. The Error Matrix for Unsupervised Classification using 50 data points in accuracy assessment.

\begin{tabular}{|l|r|r|r|r|r|r|}
\hline Unsupervised Classification & \multicolumn{7}{|l|}{} \\
\hline & Forest & Human Dist. & Juniper & Pipo/Jun & Sage/Veg & Sand \\
\hline Forest & 5 & 2 & 0 & 0 & 0 & 0 \\
\hline Human Disturbance & 1 & 2 & 0 & 0 & 0 & 0 \\
\hline Juniper & 1 & 1 & 12 & 1 & 2 & 0 \\
\hline Pipo/Juniper?? & 0 & 0 & 0 & 3 & 3 & 5 \\
\hline Sage, Veg, Grass & 1 & 0 & 1 & 0 & 10 & 0 \\
\hline Sand & 0 & 0 & 0 & 0 & 0 & 0 \\
\hline
\end{tabular}


The accuracy assessment of the supervised classification revealed similar results as unsupervised classification. The overall accuracy for supervised classification was $70 \%$ with a Kappa $=0.6053$.

Table 4. Error Matrix for Supervised Classification

\begin{tabular}{ccccccc} 
& Forest & Human Dist. Juniper & Sand & \multicolumn{2}{c}{ Sage/Veg Pipo/Juniper } \\
Forest & 5 & 0 & 0 & 0 & 1 & 0 \\
Human Dist. & 0 & 1 & 0 & 0 & 0 & 0 \\
Juniper & 0 & 1 & 7 & 0 & 3 & 0 \\
Sand & 0 & 0 & 0 & 0 & 0 & 0 \\
Sage/Veg & 0 & 0 & 4 & 1 & 10 & 0 \\
Pipo/Juniper & 0 & 3 & 0 & 0 & 2 & 12
\end{tabular}

The accuracy results are not very high and this is most likely a result of the difficulties encountered when mapping mixed and sparse stands of juniper and ponderosa. The study area also contains small drainages and these drainages are disguised by shadows and are difficult to correctly classify (Figure 5).

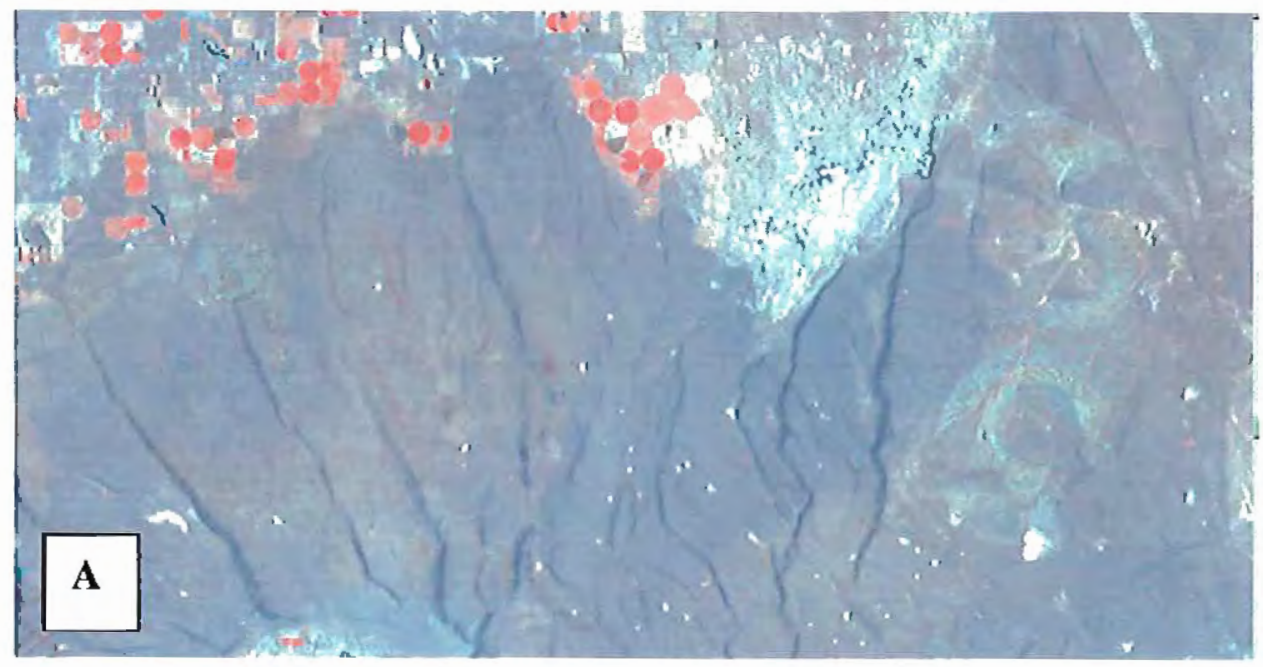




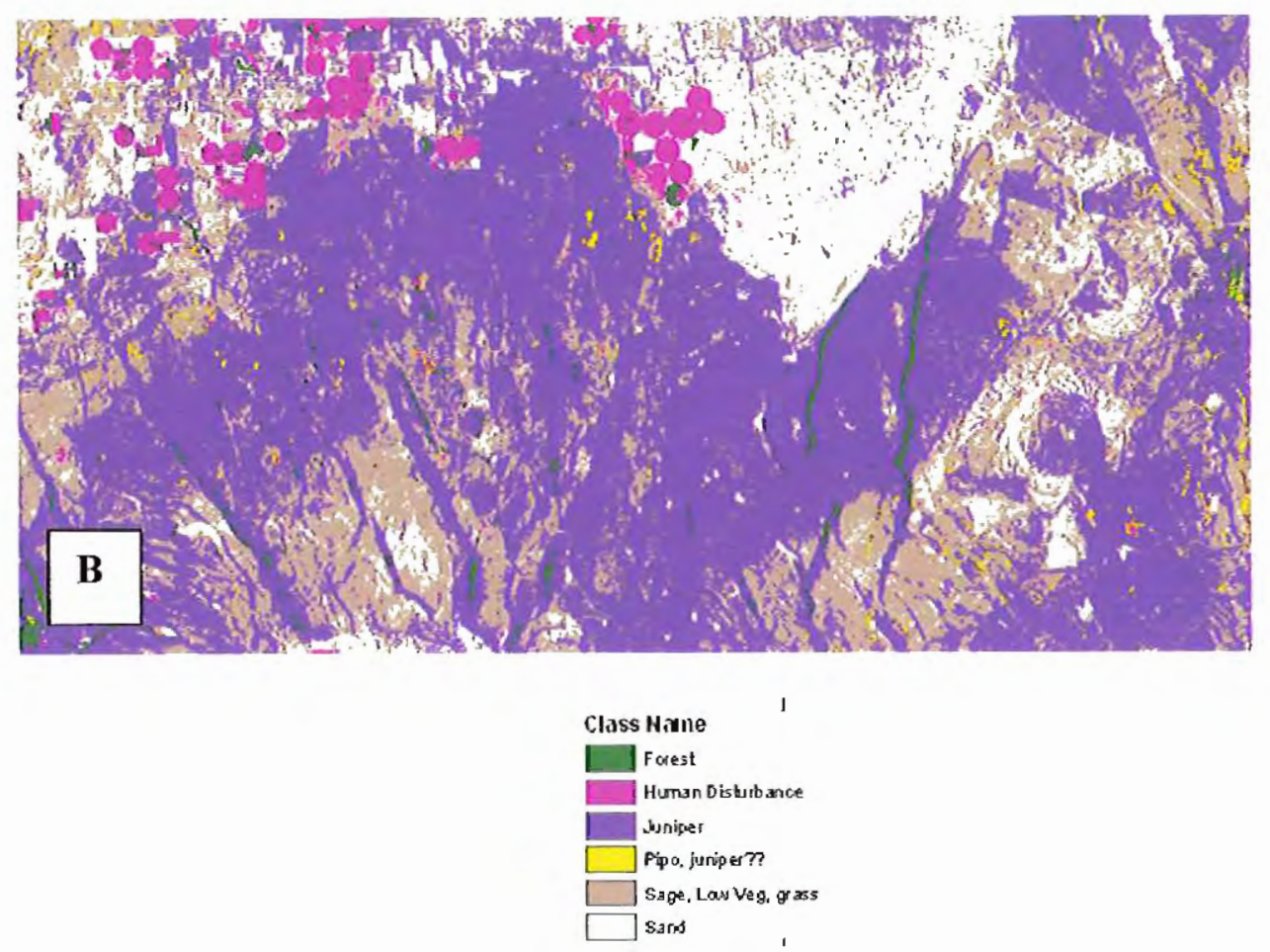

Figure 5. Shadows in the drainages of the satellite image (A) results in mislabeled pixels in the classified image (B). Note the "forest" pixels in the drainages just right of center in the classified image.

Unsupervised classification is useful in establishing preliminary classes but includes some inherent discrepancy between the classes, e.g., some pixels are falsely grouped into similar classes based upon their spectral signature because the pixels represent multiple objects with different reflectance values, a property also known as a mixel (Figure 6). This type of error was common throughout this study. Indeed, out of 40 original classes, at least six classes were of indeterminate type. 


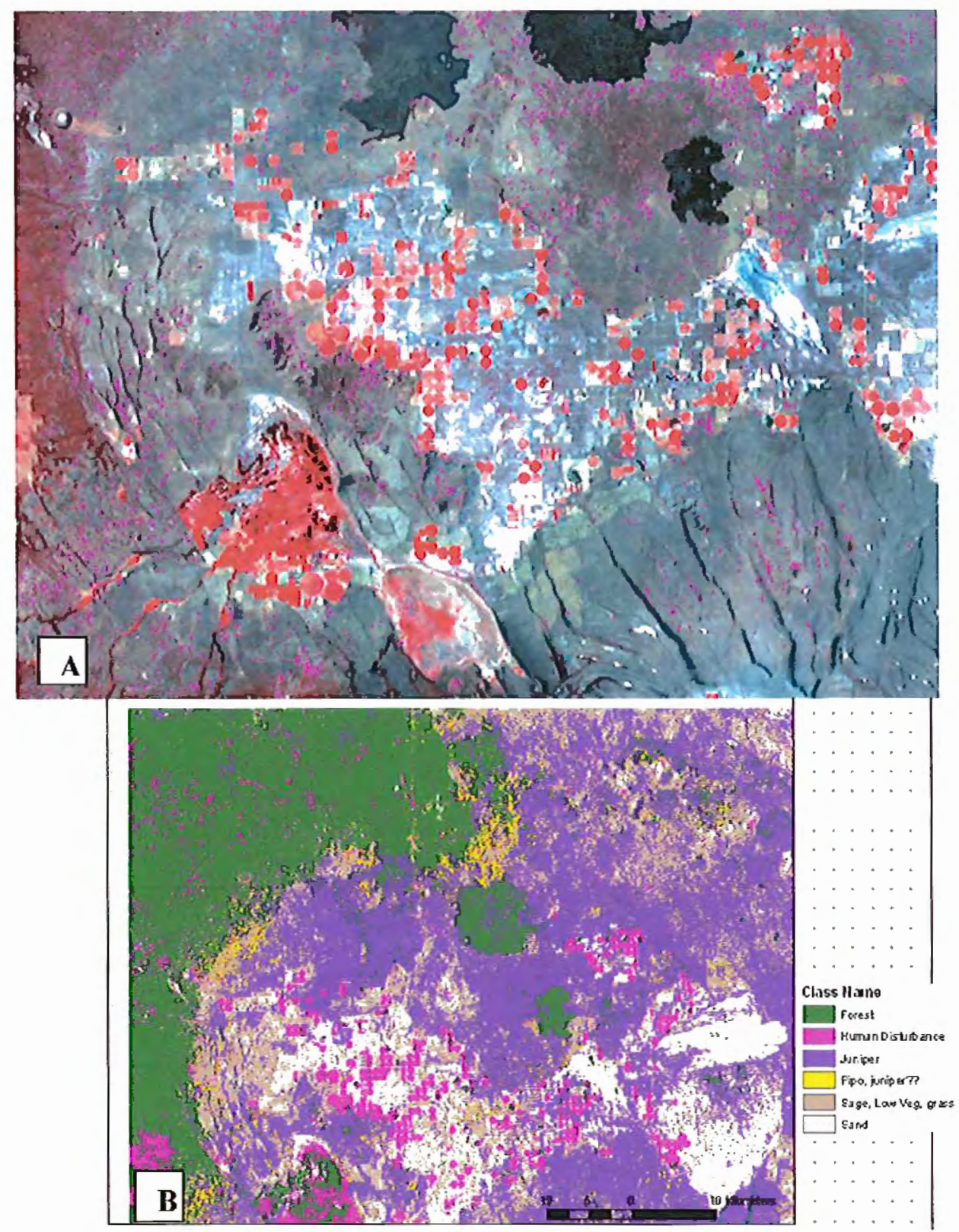

Figure 6. The satellite image of the study area boundary showing mixels (purple) identified during the unsupervised classification procedure (A). B depicts unsupervised classification results. Yellow pixels represent an indeterminate class type (mixels). 
Despite the overall inaccuracies of the classified maps, there are some redeeming qualities of the maps. The edge of the woodland and sagebrush community can clearly be seen on the classified maps (Figures $4 \& 6$ ). Areas that contain little vegetation were also generally labeled correctly. Green Mountain, which is heavily dominated by western juniper, was accurately labeled as western juniper.

Ponderosa pine trees also grow in an open park-like stands. It is difficult to properly label sparse ponderosa and juniper stands even using half-meter orthophotos. Figure 7 demonstrates the similarities in open ponderosa and juniper stands. The juniper woodlands contain large openings in the canopy $(>30 \mathrm{~m})$ and as this lends itself to errors because these gaps are the same size as a Landsat pixel. Shadows become apparent at this resolution and hinder interpretation efforts.

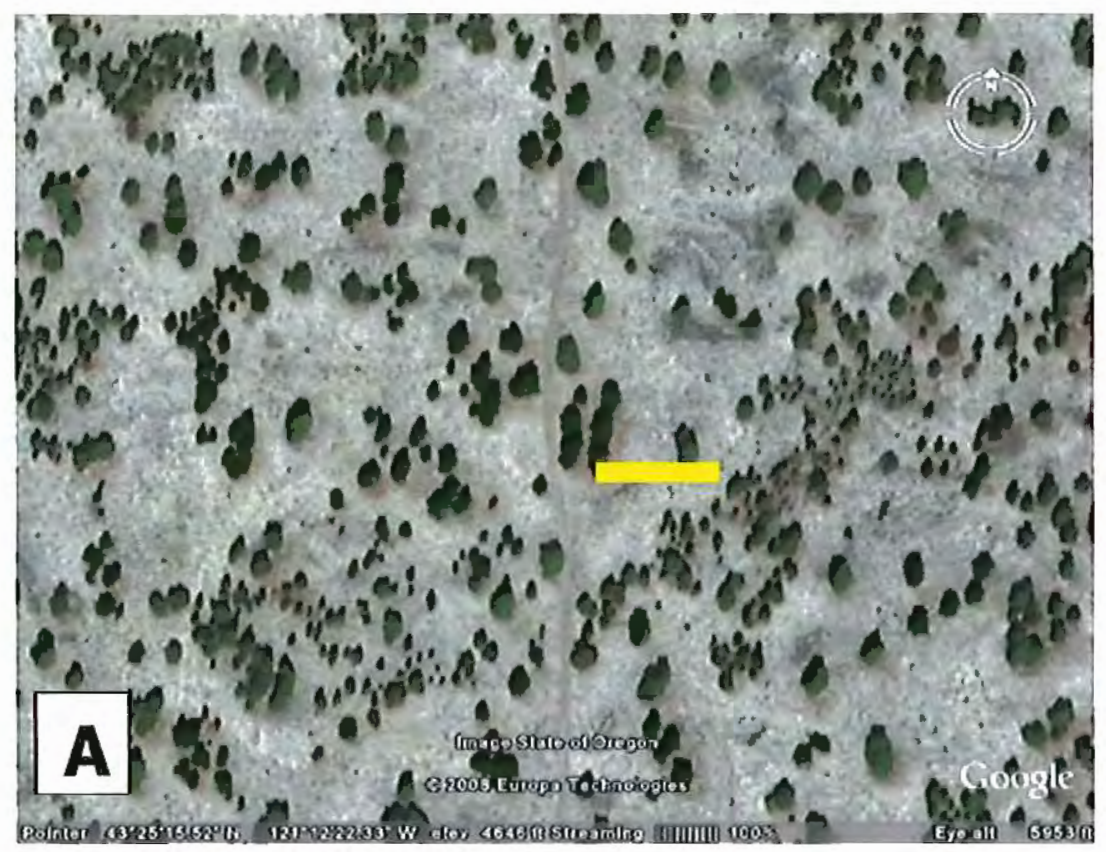




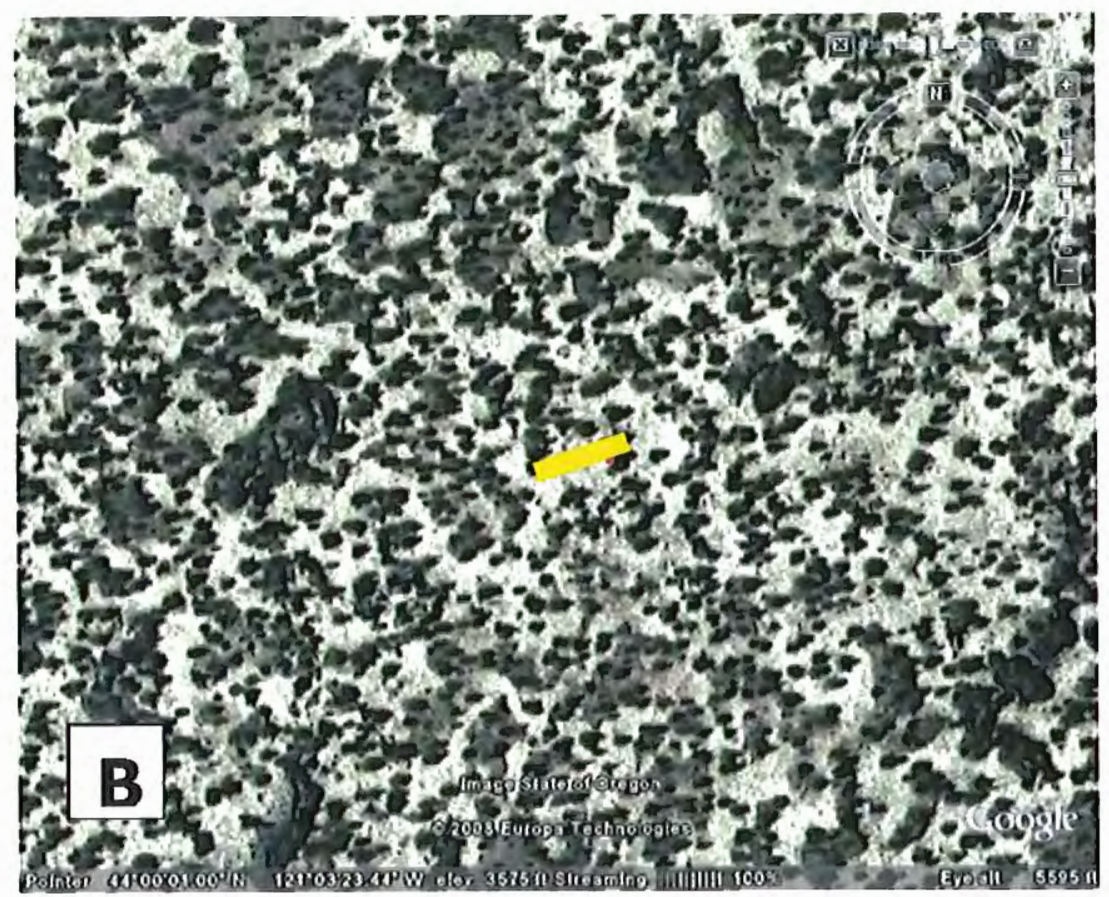

Figure 7. Open stands of ponderosa pine (A) and western juniper (B) and their respective spatial patterns. The yellow scale bars equals $\approx 36 \mathrm{~m}$.

Bare ground in open woodlands stands can influence the spectral signature of the pixel. The results of unsupervised classification are likely to be significantly influenced by bare ground. Some of the bare ground takes the form of sand dunes. Salt precipitates are also found on the ground in the study area. Locating areas of these distinct cover types will aid in future work. Saltbush (Atriplex sp.) also coexists with sagebrush on the playas. Noting homogenous fields of both saltbush and sagebrush will increase the likelihood that these vegetation types are accurately classified.

In an effort of integrate elevation into this study, I visually inspected digital elevation models of Christmas Valley. The elevation of the study area was well within the accepted elevation ranges of western juniper habitat. The transition of ponderosa pine to sagebrush appears to be more related to soil variations than to elevation gradients. 
Slope and aspect does not appear to play a significant role in western juniper establishment. The study area is relatively flat with a few small hills and which should not influence the growth patterns of western juniper.

\section{CONCLUSIONS}

The causes of western juniper aforestation are unclear and complex but appear to be a function of climate, grazing practices and altered fire regimes. Implications of aforestation are loss of biodiversity, soil erosion and altered wildlife habitat. Variables such as topography, altered fire regimes, livestock grazing and human influences may all contribute to juniper expansion. Most studies of juniper expansion are site specific and encompass areas smaller than $25 \mathrm{~km}^{2}$. There is little work done at a large landscape level with regards to western juniper expansion and which implies that there in a gap in our knowledge of this ecological phenomenon.

Other researchers have used higher resolution imagery and object oriented software to successfully map shrub encroachment in arid environments but there are limitations with these two approaches. The record for high resolution imagery spans only a few years while the record for Landsat spans more than 30 years. High resolution imagery scenes are smaller than Landsat scenes and are not of the landscape level; for example, Quickbird imaging swaths are $16.5 \mathrm{~km}$ while Landsat swaths are $185 \mathrm{~km}$. Also, the commercially available software (eCognition) for object based classification is expensive. An open source software package (SPRING) is available to the public but the developers use Portuguese instead of English making translation a concern. Juniper 
mostly grows in open, savanna-like stands and Weisberg et al. (2007) were not successful in using eCognition segmentation algorithms to scale up to an "ecotonal" level.

Generalized boundaries that incorporated large open areas into tree dominated patches (and vice versa) were common. Open patches within juniper stands will continue to be a problem for future researchers mapping juniper expansion.

In order to continue working on this topic, I will need to modify my methods and data sets. Aerial photography should be obtained and some of the methods described above could be used to map western juniper and show areas of habitat expansion. Obtaining addition ground truth data will also significantly improve the reliability of accuracy assessment. After spending a week in my study area, I have a new and better understanding of the ecological processes at work in my study area but additional data points would be useful. One of the large main areas I originally labeled juniper was actually sparse ponderosa instead of juniper. This type of mistake can be avoided in the future by addition field sampling.

Landsat is not useful for identifying individual juniper trees but it may be useful in detecting large patches of western juniper. These large patches, such as the one on Green Mountain, were identified in both supervised and unsupervised classification. The large patches of western juniper are one of the main concerns for land managers since these patches tend to have increased soil erosion and less biodiversity. Landsat may be used in the future to monitor western juniper as small stands expand and take up more area.

The Forest Service has been collecting FIA (Forest Inventory and Analysis) data for over 70 years. As a result of a Farm Bill, it is very difficult to obtain access to this 
classified dataset. Ideally, FIA data would be used both for training points in supervised classification and accuracy assessment. The Forest Service Rangeland Pilot Study was completed in 2007 and may contain useful data but it is undetermined whether the data from the rangeland study is available for public use.

GAP analysis data provides a digital source of landcover data in the United States. The gap analysis process was conceived in the 1980 s to assess the environmental conditions associated with threatened and endangered species. The original objective of the GAP project was to map areas rich in biodiversity using natural assemblages of plant species. These Landcover maps are derived from Landsat Thematic Mapper raw and hypercluster imagery from the EROS Data Center MRLC program, a federal consortium for obtaining, processing, and archiving satellite imagery.

The GAP data is useful for mapping large areas of homogeneous vegetation types but when the transition between types is indistinct, the accuracy of the classification is compromised. It was thought that the GAP data could be used in accuracy assessment of my classification but as I looked closely at the boundaries of the polygons of what was classified as juniper, I realized that their classification and lines were almost subjective as the ones I had designed. GAP data is most valid for ecoregion scale projects when the scale is $1: 100,000$ or greater but for the GAP data to be used as accuracy assessment data in this project, the data must be valid at a much smaller scale.

The Lost Forest Research Natural Area (RNA), located in the eastern section of the study area, contains a renmant stand of an ancient ponderosa pine forest that existed thousands of years ago. The Lost Forest's unique sandy soils trap moisture close to the 
surface, providing a reservoir that compensates for the lack of rainfall (Chadwick and Eglitis 2007).

It is my hypothesis that soil plays a greater role in juniper establishment in Christmas Valley than elevation. The Lost Forest is one example of the influence of soil on the potential vegetation. Future studies would include detailed soil profiles as ancillary data.

The expansion of the range of western juniper in Central Oregon is a major concern for natural resource land managers. Remote sensing methods applied to this issue can provide large-scale assessment of the afforestion of western juniper. Medium resolution imagery (Landsat) alone was not sufficient to distinguish between ponderosa and western juniper trees; however, large patches of homogeneous juniper were mapped with some degree of accuracy. This study demonstrated that ancillary data in the form of field sampling is important when creating land cover land use maps. 


\section{REFERENCES}

Adams, A.W. 1975. A brief history of juniper and shrub populations in southern Oregon. Oregon State Wildlife Commission Research Division. Wildlife Research Report No. 6, Corvallis, OR.

Azuma, D., Hiserote, B., and Dunham, P. 2005. The western juniper resource of eastern Oregon, 1999. Resour. Bull. PNW-RB-249. Portland, OR: U.S. Department of Agriculture, Forest Service, Pacific Northwest Research Station. 18 p.

Bishop, Y.M., Fienberg, S.E. and Holland., P.W. 1975. Discrete multivariate analysis: theory and practice. Cambridge, MA. MT Press.

Blackburn, W.H., Pierson, F.B., Schuman, G.E., Zartman, R.E. 1994. Variability of Rangeland Water Erosion Processes. Soil Science Society of America Special Publication 38. Soil Science Society of America, Madison, WI.

Burkhardt, J.W., Tisdale, E.W. 1976. Causes of juniper invasion in southwestern Idaho. Ecology. 76: 472-484.

Chadwick, K.L, Eglitis, A. 2007. Health Assessment of the Lost Forest Research Natural Area. United States Forest Service Publication. Central Oregon Service Center for Insects and Disease. 33p.

Definiens 2003. "Definiens Imaging, eCognition" Web page, accessed February 2008. Available at http://www.definiens-imaging.com

ERDAS, 2005. ERDAS Field Guide, Fifth Edition. ERDAS, Inc., Atlanta, Georgia, p. 770

Franklin, J., Dyrness, T., 1973. Natural vegetation of Oregon and Washington. Gen. Tech. Rep. PNW-8. Portland, OR: U.S. Department of Agriculture, Forest Service, Pacific Northwest Forest and Range Experiment Station. 417 p.

Gedney, D., Azuma, D., Bolsinger, C., and McKay, N. 1999. Western juniper in eastern Oregon. Gen. Tech. Rep. PNW-GTR-464. Portland, OR: U.S. Department of Agriculture, Forest Service, Pacific Northwest Research Station. 53 p.

Hitchcock, C.L. and Cronquist, A. 1973. Flora of the Pacific Northwest. University of Washington Press. Seattle, WA. 730 p.

Jiang, H., Strittholt, J., Frost, P., Slosser, N. 2004. The classification of late seral forests 
in the Pacific Northwest, USA using Landsat ETM+ imagery. Remote Sensing of Emironment 91: 320-331.

Johnson, D., Miller, R. 2006. Structure and development of expanding western juniper woodlands as influenced by two topographic variables. Forest Ecology and Management 229 (1-3):7-15.

Knapp, P., Soule, P. 1996. Vegetation change and the role of atmospheric CO2 enrichment on a relict site in central Oregon: 1960-1994. Amnals of the Association of American Geographers 86 (3):387-411.

1998. Recent Juniperus occidentalis (western juniper) expansion on a protected site in central Oregon. Global Change Biology 4 (3):347-357.

Knapp, P., Soule, P., and Grissino-Mayer, H.D. 2001. Detecting potential regional effects of increased atmospheric $\mathrm{CO}_{2}$ on growth rates of western juniper. Global Change Biology 7 (8):903-917.

Landsat.org, Global Observatory for Ecosystem Services, Michigan State University (http://landsat.org)

Mas., J.-F. 1999. Monitoring land cover changes: a comparison of change detection techniques. International Jommal of Remote Sensing 20(1):139-152.

Mather, P.M. 2004. Computer Processing of Remotely-Sensed Images, An Introduction. John Wiley \& Son, Ltd., West Sussex, England.

Miller, R.F., Bates, J.D., Svejcar, T.J., Pierson, F.B., Eddleman, L.E. 2005. Biology, Ecology, and Managemant of Western Juniper. Technical Bulletin 152, June 2005, Oregon State University, Agriculture Experiment Station.

Miller, R. F., and Rose. 1995. Historic expansion of Juniper-occidentalis (western juniper) in southwestern Oregon. Great Basin Naturalist 55 (1):37-45.

Miller, R. F., and J. A. Rose. 1999. Fire history and western juniper encroachment in sagebrush steppe. Joumal of Range Management 52 (6):550-559.

Miller, R. F., T. J. Svejcar, and J. A. Rose. 2000. Impacts of western juniper on plant community composition and structure. Jomrnal of Range Management 53 (6):574585 .

Miller, R.F. and R.J. Tausch. 2001. The role of fire in piñon and juniper woodlands: a descriptive analysis. Pages 15-30. In K.E.M. Galley and T.P. Wilson (editors). Proceedings of the Invasive Species: the Role of Fire in the Control and Spread of Invasive Species.Miscellaneous Publication No. 11, Tall Timbers Research Station, Tallahassee, FL. 
Miller, R.F., R. Tausch, and W. Waichler. 1999. Old-growth juniper and pinyon woodlands. Pages 375-384 in S.B. Monsen and R. Stevens, compilers. Proceedings: ecology and management of pinyon-juniper communities within the interior west. USDA Forest Service Rocky Mountain Research Station Proceedings RMRS-P-9.

Miller, R.F., Wignan, P.E., 1994. Holocene changes in semi-arid pinyon-juniper woodlands. BioScience 44: 465-474.

National Forest Inventory and Analysis. Web page. [http://fia.fs.fed.us/library/factsheets/]. Accessed June 10, 2008.

Omernik, J.M. 1987. Ecoregions of the conterminous United States. Ammals of the Association of American Geographers 77(1):118-125.

Petersen, S.L.. Stringham, T.K. 2008. Infiltration, runoff, and sediment yield in response to Western Juniper encroachment in Southeast Oregon. Rangeland Ecology and Management 61: 74-81.

Peirson, F.B., Carlson, D.H., Spaeth, K.E. 2002. Impacts of wildfire on soil hydrological properties of a steep sagebrush-steppe rangeland. International Jommal of Wildland Fire 11:145-151.

Roberts, C., Jones, J.A., 2000. Soil patchiness in juniper-sagebrush-grass communities of central Oregon. Plant and Soil 223:45-61.

Roth, A. 2004. Fire patterns within a successional gradient of a sagebrush steppe/juniper woodland. Masters Thesis, University of Idaho, Moscow, Idaho, USA.

Soule, P. T., and P. A. Knapp. 1999. Western juniper expansion on adjacent disturbed and near-relict sites. Jownal of Range Management 52 (5):525-533.

2000. Juniperus occidentalis (western juniper) establishment history on two minimally disturbed research natural areas in central Oregon. Western North American Naluralisi 60 (1):26-33.

Soule, P. T., P. A. Knapp, and H. D. Grissino-Mayer. 2003. Comparative rates of western juniper aforestation in south-central Oregon and the role of anthropogenic disturbance. Professional Geographer 55 (1):43-55.

- 2004. Human agency, environmental drivers, and western juniper establishment during the late holocene. Ecological Applications 14 (1):96-112.

SPRING: Integrating remote sensing and GIS by object-oriented data modeling. Camara G, Souza RCM, Freitas UM, Garrido J Computers \& Graphics, 20: (3) 395-403, 
May-Jun 1996.

Strand, E.K., Robinson, A.P., Bunting, S.C. 2007. Spatial patterns on the sagebrush steppe/Western juniper ecotone. Plant Ecology 190: 159-173.

Vasek, F.C. 1966. The distribution and taxonomy of three western junipers. Brittonia 18:350-372.

Waichler, W., Miller, R.F., Doescher, P. 2001. Characteristics of old-growth western juniper woodlands. Journal of Range Mangemem 54(5):518-527.

Wallace, O.C., Qi, J. Heilma, P., Marsett, R.C., 2003. Remote Sensing for cover change assessment in southeast Arizona. Journal of Range Management 56: 402-409.

Wall, T. G., R. F. Miller, and T. J. Svejcar. 2001. Juniper encroachment into aspen in the Northwest Great Basin. Journal of Range Management 54 (6):691-698.

Weisberg, P.J., Lingua, E., Pillai, R.B., 2007. Spatial patterns of Pinyon-Juniper Woodland expansion in Central Nevada. Rangeland Ecology Management 60: 115-124.

Wood, M.K. 1988. Rangeland vegetation-hydrologic interaction. (Eds. Tueller, P.T.) Vegetation Science Applications in Rangeland Analysis Management. Kluwer Academic Publishers, Boston 
Paleosols: Their Definition, Identification, and Interpretation with Reference to John Day Fossil Beds National Monument

Elizabeth A. Goralski

Submitted for partial fulfillment of Master of Science degree in Geography

Portland State University

Approved by:

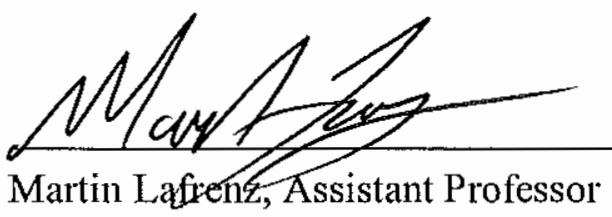

Joseph Poracsky, Professor and Acting Department Chair

Date:

28 Angurt 2008 


\title{
Paleosols: Their Definition, Identification, and Interpretation with reference to John Day Fossil Beds National Monument
}

\author{
Elizabeth Goralski
}

August 25, 2008

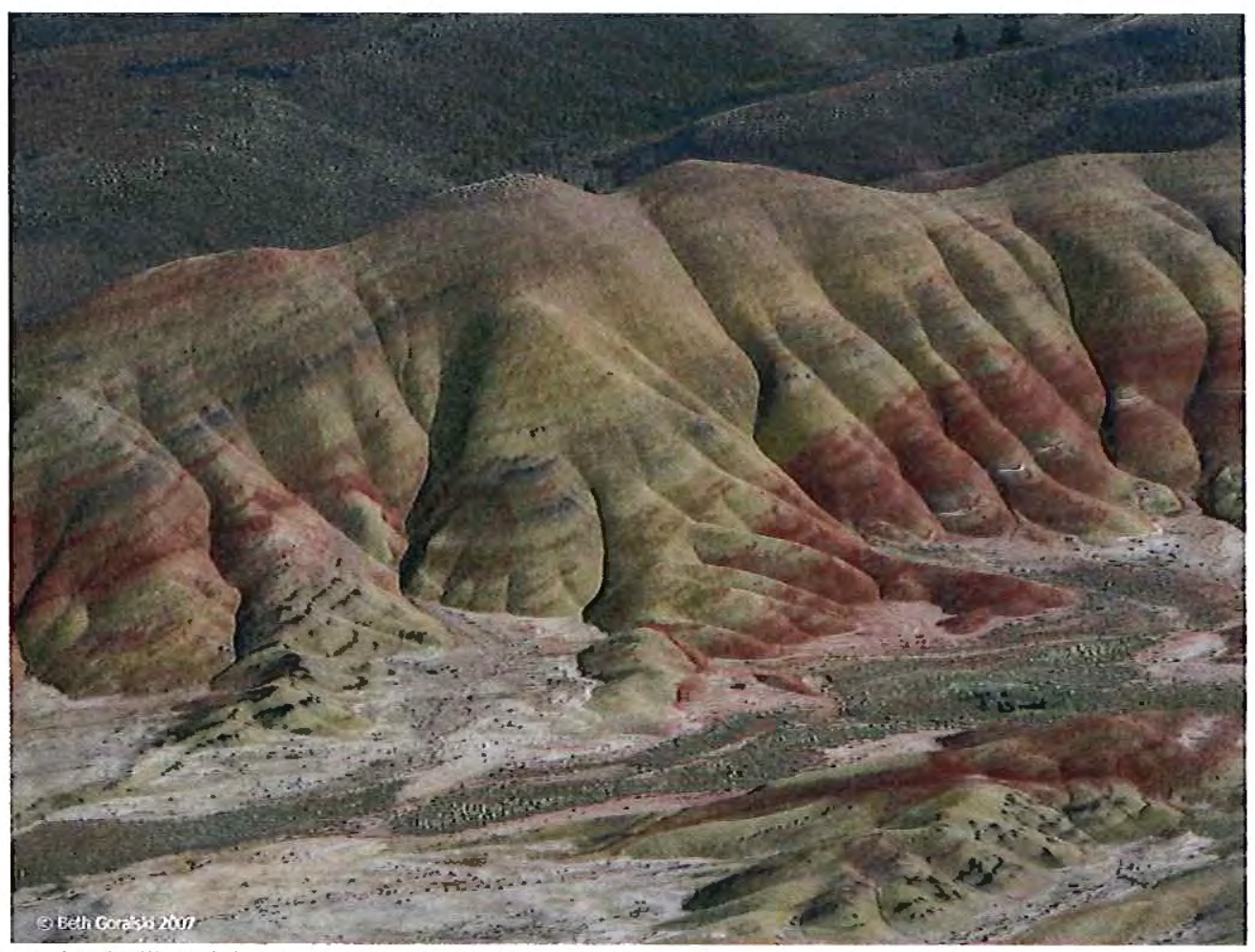

Painted Hills Unit in John Day Fossil Beds National Monument 


\title{
Paleosols: Their Definition, Identification, and Interpretation with reference to John Day Fossil Beds National Monument
}

\author{
ABSTRACT \\ Paleopedology is the study of ancient soils and paleosol is the term used to denote \\ an ancient soil. Paleosols provide a preservation environment and context for fossil \\ plants and animals, and can be considered trace fossil ecosystems. Three main types \\ of evidence are used to recognize paleosols: traces of land life, soil horizons and soil \\ structure. This paper presents an overview of the history of paleopedology and \\ focuses on the John Day National Monument in Central Oregon because of its well \\ known paleosol and fossil record.
}




\section{TABLE OF CONTENTS}

I. INTRODUCTION

A. HISTORY OF PALEOPEDOLOGY

II. PALEOSOLS OF JOHN DAY NATIONAL MONUMENT

A. HISTORICAL AND CURRENT CLIMATE OF THE JOHN DAY FOSSIL BEDS

B. THE TERTIARY ENVIRONMENT

C. TRACES OF LAND LIFE

D. ROOT TRACES AND BURROWS

E. PLANT REMAINS

F. SOIL HORIZONS

G. SOIL STRUCTURE

H. BURIAL ALTERATION OF PALEOSOLS

III. SUMMARY AND CONCLUSIONS

IV. REFERENCES 


\section{INTRODUCTION}

Paleopedology is the study of ancient soils. First coined by the Russian soil scientist Boris Polynov, paleosol is the term used to describe the remains of an ancient soil $($ Greek palaios $=$ ancient,+ Latin solum $=$ ground $)$. Paleopedology is a relatively young field of science but provides an important tool for reconstructing past environmental conditions. In this paper, I explore how paleosols are used for climate reconstructions and why scientists debate what constitutes a paleosol. I focus on the John Day National Monument in Central Oregon because of its well known paleosol and fossil record. In my conclusions, I suggest future topics for research in paleosol and climate reconstruction.

\section{History of Paleopedology}

The history of paleopedology can be traced to the early theoretical contributions to soil science. The fundamentals of modern soil science were developed by Vasily Dokuchaev in Russia during the late 1800s. Dokuchaev's work demonstrated that soils could be described, mapped and classified in a scientific manner. In addition to mapping and classification, he showed that various components of soils are related to environmental factors, including climate. Subsequent efforts to map zonal soils across large areas revealed unusual characteristics among certain soils; some soils appeared to be very old. In 1927, Boris Polynov, another Russian, summarized the existence of these 
older soils and established the scientific framework for paleosol research. His short paper introduced the term paleopedology (Polynov 1927).

Although the term paleosol has been used for several decades, the criteria underlying the definition of paleosols have been contested. Central to the debate are questions regarding soil formation and what constitutes a soil. Based on Dokuchaev's earlier work, Hans Jenny (1941) identified five soil forming factors: climate, organisms, relief, parent material and time that could be used to characterize soils at a given location. This approach to understanding pedogenesis has since been widely adopted by soil scientists, yet it is complicated by the existence of partially or completely burial soils. These latter soils were the basis for Ruhe's (1956) definition of a paleosol. Bos and Sevink (1975) argued that a soil buried in some locations and present as a surface soil in other locations should also be classified as a paleosols. Fenwick (1985) countered this idea suggesting that the term paleosol only be applied to soils isolated from present pedogenic processes by burial. Retallack (2001), however, noted that not all paleosols are or have been buried.

Some soil scientists have sought to place age limits on a paleosols (Duchaufour 1982, Tarnocai and Valentine 1989). These authors suggest paleosols be defined by the timing of significant changes in one or more soil forming factors and the resultant change in pedogenesis. For example, the role of different climate epochs such as the Pleistocene and the Holocene is suggested as one mechanism to delineate between paleosols and contemporary soils (Bronger and Catt 1989). Despite the debate over a formal definition for paleosols, these soils possess several characteristics indicative of paleopedogenic processes. 
Much of paleopedology has been concerned with Quaternary age soils. In 1965, the Seventh Congress of the International Association for Quaternary Research coordinated the Commission on Paleopedology. Studies across the globe were conducted on Quaternary stratigraphy and geomorphology. Beginning in the 1960's interest in preQuaternary paleosols increased following their discovery in many non-marine sedimentary sequences (Retallack 1997) and deep-sea cores (Ford, 1987).

The fossil record of the John Day Fossil Beds of Central Oregon represents a significant contribution to our knowledge of pre-Quaternary floras and faunas.' Paleosols associated with these fossils provide an environmental context for plant and animal fossils and evidence of Earth's climate changing.

\section{PALEOSOLS OF JOHN DAY NATIONAL MONUMENT}

\section{Historical and Current Climate of the John Day Fossil Beds}

The John Day Fossil Beds are located in Central Oregon near the small town of Mitchell in Grant County (Figure 1). In the 1860's soldiers discovered preserved fossil leaves in the Painted Hills. Thomas Condon, a Congregational missionary in The Dalles, made the first scientific collection of the plant and animal fossils in 1865 (Clark 1989). Since then, many amateur and academic researchers have helped develop a comprehensive fossil collection in the Clarno and Painted Hills areas. The John Day fossil beds continue to contribute new fossil records and insights into Oregon's Tertiary environment. Presently, the climate at the fossil beds tends to be hot and dry in the 
summer months with temperatures exceeding $37^{\circ} \mathrm{C}$. Winters are cold, averaging $-4^{\circ} \mathrm{C}$ daily temperatures with occasional snow and rain (John Day Fossil Beds National Park website).

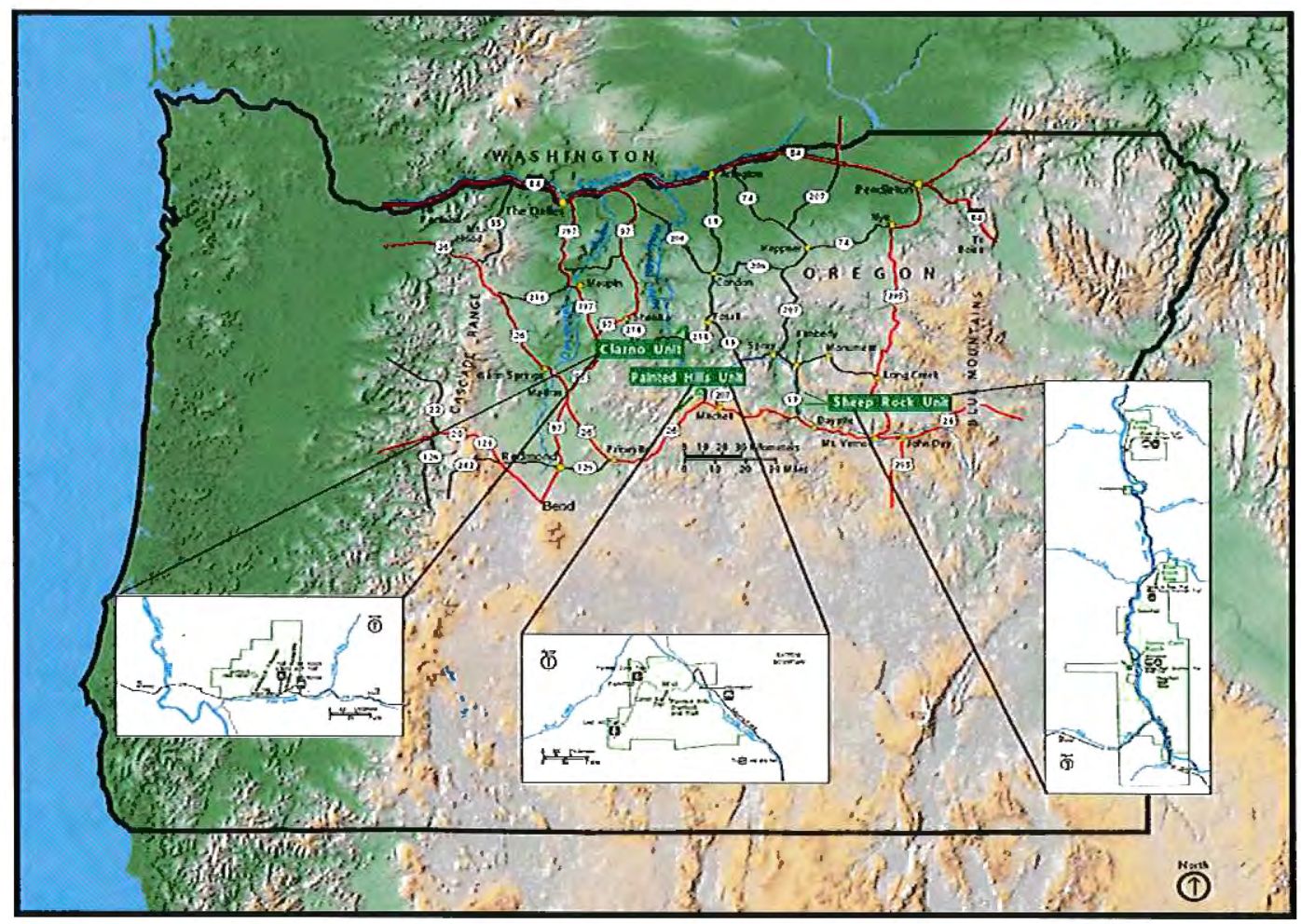

Figure 1. Location of the Clarno, Painted Hills, and Sheep Rock units of the John Day Fossil Beds National Monument. Image from the John Day Fossil Beds National Park website: http://www.nps.gov/joda/planyourvisit/directions.htm

\section{The Tertiary Environment}

Radiometric dating of the ash flows and tuffs date the Clarno formation as midEocene (Bestland et al. 1997). During this period, the Clarno area (Figure 2) was a mountainous region of imposing volcanic peaks (Wolfe et al., 1998). The conglomerates include deposits of braided streams, alluvial aprons, and volcanic lahars flanking active 
andesitic stratovolcanoes (White and Robinson, 1992). The Clarno-John Day formation transition was associated with a tectonic shift in the Pacific Northwest. This shift caused the Clarno volcanic arc to become dormant and replaced by a new arc further to the west (Robinson et al., 1984, 1990). Deposition of the John Day Formation occurred during the middle Eocene to late Oligocene (Bestland et al., 1997) when most of eastern Oregon was a terrestrial backarc basin to an ancestral Cascades volcanic arc in the current area of the Western Cascades (Robinson et al., 1984, 1990).

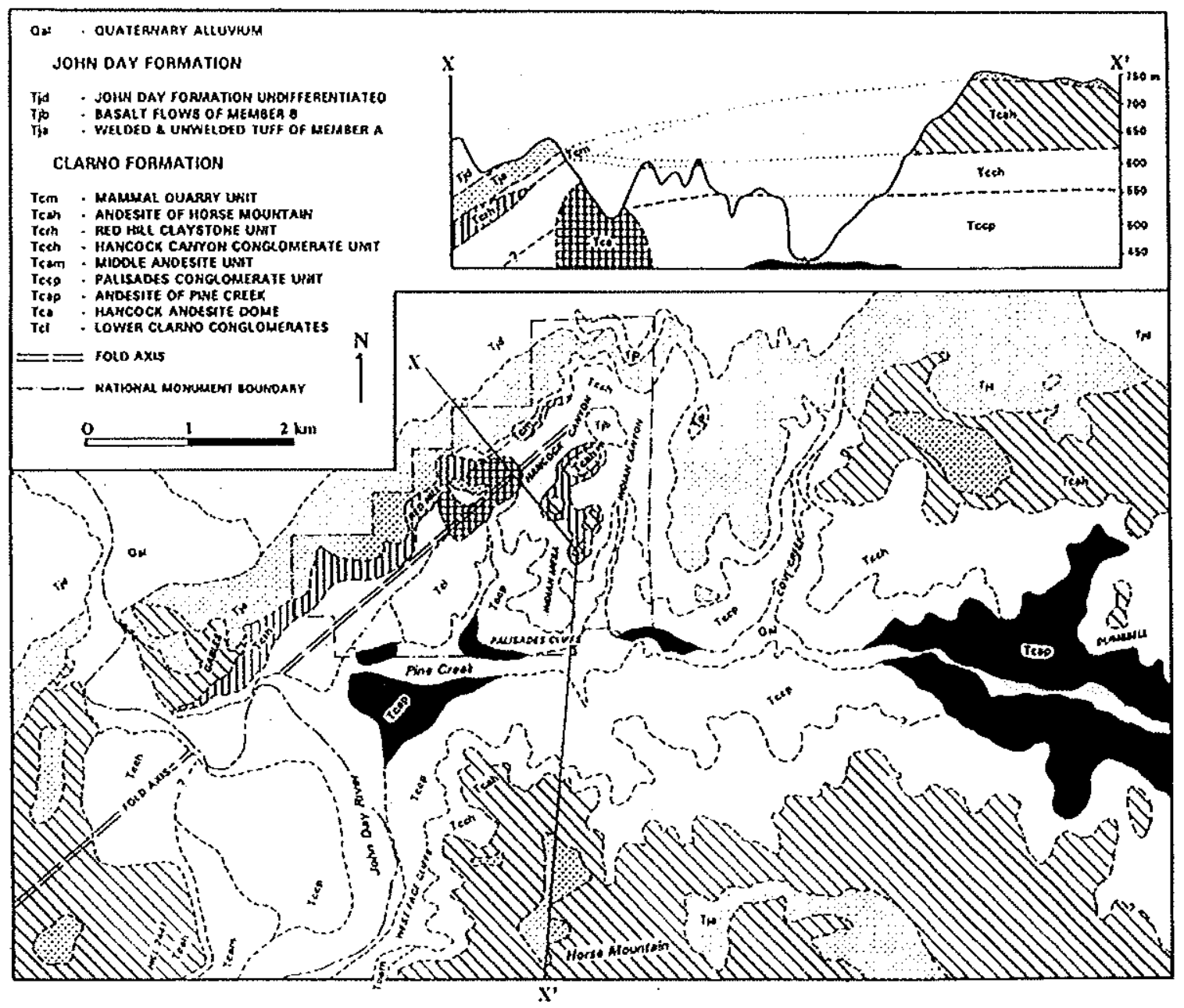

Figure 2. Generalized geologic map and cross section of the Clarno Unit of the John Day Fossil Beds National Monument (from Bestland et al. 1994). 
Paleosols of the upper John Day Formation formed largely on redeposited rhyodactic volcanic ash that varies little in chemical or mineral composition (Retallack et al., 2002). Volcanic shards are common, and chemical analyses indicate that the paleosols found in this formation are little altered from their parent material (Bestland, 2000). Some paleosols formed directly on fresh volcanic airfall ash, but most paleosols were formed on weathered ash was been redeposited by wind and water.

There are three main kinds of features used to recognize Eocene and Oligocene aged paleosols at the John Day Fossil Beds: traces of land life, soil horizons, and soil structure. These primary diagnostic elements are generally used when sampling paleosols in the field. Paleosols collected in the field routinely undergo laboratory analysis for further assessment.

\section{Traces of Land Life}

Traces of plant and animal life are one of the best indications of paleosols. Fossil root traces indicate plant growth associated with the paleosols. Animal features such as krotovinas further indicate bioturbation in paleosols. The term krotovina is commonly used to refer to channels, voids and nests of different soil organisms that are filled and compacted by soil materials. Krotovinas are classified based on their shapes, internal fabrics and separability from horizon soil matrix (Ghorbani and Karmian, 2007).

Krotovinas include pedotubules resulting from cicadas and other insect activities in soil.

Not all paleosols contain plant and animal remains. Precambrian paleosols and Antarctic soils lack evidence of biological activity because of the limited presence of 
terrestrial life (Retallack, 1990a). Plant remains also undergo varying degrees of epigenesis (fossilization) depending on the depositional environment and the structural characteristics of the plants. The Clarno and John Day Formations have a profusion of well preserved plant and animal fossils.

\section{Root Traces and Burrows}

Root traces and burrows are common in the Clarno and Painted Hills formations. Burrows are constructed by sinall animals and insects such as cicadas and earthworms. While often similar in appearance to burrows, root traces can be distinguished by their distinctive geometry. Most root traces taper and branch downward and are irregular in width. Burrows are generally parallel sided and branch systematically. The degree of compaction in a paleosol can be inferred by the deformation and compression of burrows and root traces. Occasionally, root traces have been obscured by burrows and vice versa. In other cases, root traces are obscured by mineralized overgrowths and fillings by ironmanganese nodules (Pratt, 1988). In other paleosols, well-preserved fossil root traces with original carbonaceous material of the roots can be found. Burrows in paleosols may be valuable indicators of paleoenvironmental conditions, especially when it is possible to distinguish what creature made the burrow. Earthworms, millipedes, bees, termites, ants and rodent burrows can be distinguished when they are clearly preserved (Retallack, 1984, 1990; Hasiotis and Dubiel, 1995). None of these creatures can tolerate water logged soil and the depth of penetration of their burrows inay indicate the former level of the water table. 
The paleosols in the Clarno and John Day Formations have surprisingly low amounts of organic matter relative to the amount of root traces, burrows and other evidence of life they contain. This loss of organic material leads to higher Munsell chroma readings. The loss of organic material also makes the paleosol more prone to popcorn weathering (Retallack, 1991d) which is a surface texture produced by the clay shrinking and swelling with the weather.

Many root traces include drab haloes (drab hollows), diffuse zones of grey-green to blue-grey clay extending outward from the sharp inner boundary of the root hole. The most likely explanation for drab haloe root traces is anaerobic decay around the root at the time of burial. Dead roots would have decayed aerobically in lowland soils and would have decayed anaerobically only after burial. Thus, drab haloed root traces represent the last crop of vegetation before burial and are an important indicator of the former vegetation. Drab haloes are not considered part of ancient rhizospheres because they extend from the stout parts of the root traces as well as from the fine rootlets. By contrast, the active part of the rhizosphere is located around the tips of the rootlets where there are abundant root hairs rather than near the main root stalk (Russell, 1977).

\section{Plant Remains}

The Painted Hills area of the John Day Formation includes fossil leaf litter found in swamp and lacustrine facies. Fossil pollen, leaf impressions, and silicified wood are found in several drab colored and weakly developed paleosols (Cmuk, Luquem, Micay, Patat, Sayayk paleosols). The presence of manganese nodules, drab color, and lack of soil differentiation in the paleosol suggest wet and mesophytic vegetation types 
(Retallack, 1998). Red paleosols represent vegetation of well-drained sites in which plant remains are seldom preserved. The preservation of leaves is mostly from impressions rather than compressions. Impressions are expected on moderately aerated, weakly developed soils (Retallack, 1998).

The most famous collection of plant fossils, the Clarno Nut Beds, contains plant fossils derived from transported assemblages. These assemblages are associated with paleochannel fluvial deposits or a lahar-runout derived conglomerate (Manchester, 1981). Paleosols in the Clarno Formation includes plants such as the horsetails (Equisetum clarnoi) in the Luquem paleosol that are preserved in a growth position and extend into the overlying strata. Rapid burial within lahars and hyper-concentrated flows may explain this type of preservation. Burial and regrowth of horsetails is common in marshes and riverbanks and have been found in sediment deposits extending into the Mesozoic Era (Gastaldo, 1992).

The fossil soils in the John Day Formation include evidence of bunch grasses and open, semi-arid vegetation as old as late Oligocene (Retallack, 2004). These early rangelands are comparable to those presently found in the North American Great Plains. Before 19 Ma, most paleosols in the region included large calcareous nodules, similar to the paleosols found throughout the Cenozoic in the Great Plains. These nodules are uncommon in subsequent younger deposits.

The silica and shallow carbonate horizons found in paleosols provide evidence suggesting dry climates ( $<400 \mathrm{~mm}$ mean annual precipitation). These horizons along with the shallow fossilized rooting depths indicate that these soils developed in the presence of short grasses. Paleosols of sod grasslands have abundant, filamentous (less 
than $2 \mathrm{~mm}$ diameter) fossil root holes and common, rounded pellets of earthworms and other crumb peds (Retallack 2004). Soil organic matter, actual roots and other body fossils of grasses are seldom preserved in grassland paleosols because grasslands, unlike marshes and fens, are well drained and oxidized, allowing organic matter to decay after burial (Retallack, 1998).

Phytoliths are rigid, microscopic mineral grains found in many plants. The most common type of phytolith is the silicon phytolith which is also commonly known as the 'opal' phytolith. The phytolith is an additional line of evidence for the presence of grasses (Stromberg, 2002). Opal phytoliths accumulate in the soil and are abundant in the paleosols in Oregon (Retallack 2004).

Early Miocene age short grasslands in Oregon are consistent with the increased abundance of grass pollen in rocks of that age in the Pacific Northwest (Leopold et al. 1992). A sod grassland interpretation is also compatible with the findings of hypsodont parahippine horses (MacFadden and Hulbert, 1988). Parahippine refers to the genus of the ancestral horse while hypsodont refers to the structure of the tooth. Hypsodont dentition is characterized by high-crowned teeth and enamel which extends past the gum line. These parahippine horses have been identified as grazers based on their tooth morphology and wear.

\section{Soil Horizons}

Like modern soil horizons, paleosol soil horizons vary depending upon the environmental conditions during pedogenesis. Horizons of paleosols are often distinct 
from other stratigraphic layers as they represent unconformities resulting from the truncation of the uppermost horizon by erosion. Conversely, boundaries between lower horizons and underlying parent material, are typically gradational (Retallack, 2001). Soil horizons provide clues to past vegetation of paleosols and the duration of soil formation. Soils of young surfaces, such as flood plains or landslides, exhibit a distinct layered structure. Young soils support early successional vegetation and have only an A horizon over mildly weathered parent material (C horizon). This simple horizon structure, A over C, characterizes a limited period of pedogenesis. Over time, pedogenesis results in thicker subsurface horizons exhibiting enriched concentrations of organic matter and clay. Thus, horizons can be used to assess the relative degree of development of paleosols. Rough estimates in years can be extrapolated from current studies of modern soils of various ages (chronosequence) (Birkeland, 1984).

Horizon thickness, grain size, color, reaction with acid, and the nature of horizon boundaries are recorded in the field and used to interpret the history of paleosols. The descriptive shorthand used in modern soil science can also be used to describe paleosols. Some paleosol horizons are lithologically distinct and have been given special names; for example, cornstone (nodular calcareous or Bk horizons) and ganister (silicified, nearsurface sandy or E horizons) (Retallack 1997).

Paleosols follow the conventional classification used by the National Corporative Soil Survey of the United States (Soil Survey Staff, 1975). This allows paleosol to be classified using contemporary soil orders such as Vertisol, Entisol, or Mollisol. The naming convention of paleosols differs when one arrives at the series level. The term pedotype was coined by Retallack (2000) to distinguish a paleosol soil series from a 
modern soil series. The John Day and Clarno Formations contain 26 different pedotypes and 511 individual paleosols. The pedotypes recognized here have been named using simple descriptive words from the Sahaptin Native American Language (DeLancey et al., 1988).

Paleosol surface horizons are often enriched in organic matter. Valentine and Darlymple (1976), for example, found an $\mathrm{A} / \mathrm{Bwb}$ horizon contained 1.7 per cent organic matter-70 per cent more than the $\mathrm{Bw} / \mathrm{C}$ horizon located above but less than 20 per cent more than the Bwb below. Unfortunately, organic rich horizons are generally surface horizons and highly susceptible to erosion.

Attempts to establish the existence of pedogenically produced organic matter using micromorphology have largely been unsuccessful because of decomposition and compaction of the original organic matter. However, amino acids have been identified in allophane-rich soils in New Zealand. Limmer and Wilson (1980) demonstrated that several amino acids will survive for at least $40 \mathrm{ka}$ and provide a means for identifying former A horizons.

Color is the most obvious characteristic that attract our attention to a paleosol, as demonstrated by the colors of the Painted Hills (Figure 3). The color of the Painted Hills is a byproduct of warmer past conditions. Some samples of well-indurated or partly metamorphosed paleosols maintain their color but little-altered clayey paleosols may loose their color upon exposure or laboratory storage. In the Badlands of South Dakota, rock samples become paler after drying in the sun and after several months of storage these same rocks will change color from grayish green to yellow because of the oxidation 
of their reduced iron-bearing minerals (Retallack, 1988). It is thus advisable to record color using a Munsell Color Chart within a few minutes of exposure.

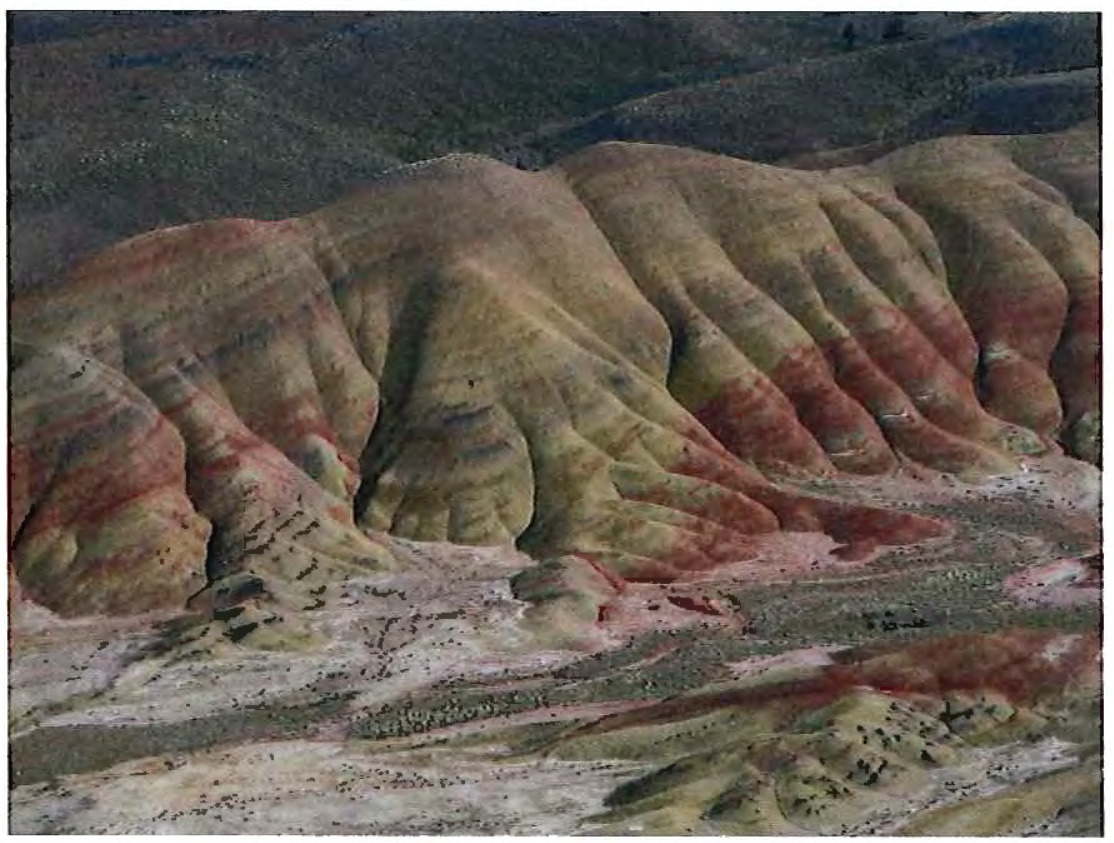

Figure 3. The Painted Hills Unit in the John Day Fossil Beds illustrates the vivid colors of paleosols.

In some of the John Day paleosols (Scat, Patat, Micay, Kskus, Maquas, Xaxus and Yapas pedotypes) the highest clay percentage of the profile occurs in the uppermost $30 \mathrm{~cm}$. This is the 'clayey surface horizon' characteristic. One explanation for this feature is the slow addition of sedimentary and volcanic air particles to the soil fabric. Weathering with eolian influx is now widely recognized in soils, including those developing under topical rainforests (Brimhall et al. 1988; Muhs, et al. 1987).

Some John Day paleosols (Xaxus and Yapas pedotypes) have calcareous nodules and dispersed calcite. The nodules preserve a variety of features of carbonate accumulated during soil formation. Nodules encrust and enclose fossil bones and can be attributed to local fluctuations in groundwater chemistry (Downing and Park, 1998). 
Many of the paleosols contain a dark brown to blueish black, opaque patches of non-crystalline iron-manganese on slickenslided argillans, as nodules or concretions in the matrix, or as void fills after root traces (Retallack, 1999). The Lakim paleosols are unusual in that they show accuinulations of manganese. Black spots up to $1 \mathrm{~m}$ are a conspicuous feature of the Lakim paleosols in the flats below the Visitor Overlook in the Painted Hills. Pickford (1974) notes that there are similar manganese concentrations around the roots of the inodern toothpick tree (Dobera glabra). Thus far, no manganese facilitating plant has been identified in the Eocene/Oligocene fossil flora but this explanation for the black spots remains feasible.

\section{Soil Structure}

Unlike sedimentary layering, metamorphic foliation and igneous crystallization, the soil structure of paleosol is often described as 'massive', 'jointy', 'structureless', 'veined' and 'mottled'. These terms suggest that paleosols are fossil soils and not remnants of other geological process. Soil structures are important to the interpretation of paleosols, especially with regards to the drainage and chemical behavior.

Stable aggregates of soil material (peds) are bound by both cutans and open spaces or voids in the soil. Cutans are modified surfaces of peds, clasts or crystals. Both cutans and peds are classified according to size and shape. For example, an argillian is a clay skin and one type of cutan. The origin of cutanic features usually falls into three categories: those formed by washing down of material into cracks (illuviation cutans), those formed by progressive alteration inward from a surface (diffuse cutans) and those 
formed by differential shear forces within the soil (stress cutans) (Retallack, 2001). Illuviation cutans are the most clearly diagnostic of paleosols. The elaborate system of cracks and hollows in the soil allow air and water to transfer through the soil. Illuviation cutans contain material washed in before the soil became compacted. In many paleosols, these features would have been crushed out of existence but modifications of the hollows such as staining with iron oxide can help determine past structural systems.

Local concentrations of specific minerals are also common in soils and are usually hard, distinct, calcareous, ferriginous or sideritic lumps. These minerals can form glaebules, nodules, tubular features and crystals. These structures can also be found in marine sediments and are not diagnostic characteristics of paleosols but are an important part of their structure. Soil structures are important in understanding the drainage and chemical behavior of paleosols. For example, crumb and granular structures are indications of biological activity. This is evidence for high soil fertility and is indicative of grassland soils (Mollisols). Domed columnar peds form in soils where the clays are saturated with sodium cations. This structure is most commonly found in marineinfluenced soils of mangal and salt marshes and also in desert soils formed around salt pans.

\section{Burial Alteration of Paleosols}

Many, but not all, paleosols are buried after formation. Metamorphic alterations can seriously affect the recognition and interpretation of paleosols. Diagenesis is the alteration of sediments after deposition. Soil on the earth's surface usually forms at 84 
${ }^{\circ} \mathrm{C}$ to $-88{ }^{\circ} \mathrm{C}$ (Kimmins, 1997). The transition from diagensis to metamorphism is passed at temperatures somewhere in excess of $200^{\circ} \mathrm{C}$ or depths of $7 \mathrm{~km}$. The deeper a paleosol is buried, the warmer it becomes and metamorphic alterations begin to occur. Destruction of primary soil features and imposition of metamorphic foliation, schistosity and crystalline texture can limit paleosol interpretation.

Diagenesis can include loss of organic matter, burial gleization, burial reddening, calcite cementation, silification, zeolitization, celadonitization, illitization, feldspathization, compaction, thermal'maturation of organic matter and recrystalization. Some but not all of these processes are present in the paleosols found in the John Day Fossil Beds.

Studies of Quaternary paleosols have shown that soon after burial, paleosols lose up to an order of magnitude of organic carbon as determined by the Walkley-Black technique (Stevenson 1969), but paleosols may preserve the general trend of decreasing organic material with depth. The paleosols in the Clarno and John Day Formations contain low concentrations of organic matter leading to a higher Munsell chroma. The loss of organic material also makes the paleosol more prone to popcorn weathering (Retallack, 1991d).

Burial reddening is another feature common to paleosols. Most soils are a brownish red but many paleosols are a fire engine red (Munsell hue 5YR or redder). The degree of redness of soils is primarily the result of the nature and grain size of iron oxide and hydroxide minerals (Hurst 1997, Blodgett 1988). These minerals are formed by oxidation during weathering of iron-bearing minerals in the parent material. As weathering continues, the brown hydroxides dehydrate and recrystallize to the coarser 
grain size and redder color of hematite. Retallack (2001) also theorizes that burial reddening occurs when ferric hyroxides are dehydrated. One example is the transformation of goethite to hematite (Blodgett et al., 1993). These changes in color compromise the interpretation of paleosols because the dehydration of ferric hydroxides can also occur with increasing age and climatic temperature during the formation of the surface soil (Birkeland, 1984).

Permineralization occurs after burial, as the empty spaces within an organism (spaces filled with liquid or gas during life) become filled with mineral-rich groundwater and the minerals precipitate from the groundwater, thus occupying the empty spaces. Occasionally, wood, seeds, and sedimentary layers become permineralized. In the Clamo Nut Beds, this can be attributed to local hydrothermic alteration (Hanson, 1996). Wood cell walls are preserved and their lumens are filled with silica (Manchester, 1977). Fossil wood ranges from moderately to poorly preserved in paleosols in the Painted Hills (Retallack 2000).

Paleosols of the upper and middle Big Basin and lower Turtle Cove Members were primarily altered by a combination of zeolitization, celadonitization and feldspathization. Zeolites are commonly found in hotsprings, cooling volcanic rocks and alkaline lakes (Barger 1994), but rarely in soils. Zeolitic and celadonitic alteration may be signatures of paleosols that were originally Andisols. Illitization occurs in clayey paleosols when smectite is destroyed and illite grows by transfer of potassium from the dissolution of potassium bearing minerals.

Ratios of various elements are often used to establish paleosol formation in situ. Both Titanium and Zirconium are considered immobile elements (Hodson, 2002) and 

(Barger 1994), but rarely in soils. Zeolitic and celadonitic alteration may be signatures of paleosols that were originally Andisols. Illitization occurs in clayey paleosols when smectite is destroyed and illite grows by transfer of potassium from the dissolution of potassium bearing minerals.

Ratios of various elements are often used to establish paleosol formation in situ. Both Titanium and Zirconium are considered immobile elements (Hodson, 2002) and $\mathrm{Ti} / \mathrm{Zr}$ ratios in the underlying rock layer should be nearly identical to those in the overlying paleosol profile if there is no geological discontinuity (Tsai and Chen, 2000; Schaetzl and Anderson, 2005).

Burial of paleosols results in compaction as the void spaces and fossils are crushed by the weight of over lying material. The compaction of originally loose soil clods against one another creates a complex pattern of slickenslides, which are superficially similar to the slickenslides of swelling-clay soils in seasonally dry climates (Gray and Nickelsen 1989). Clastic dikes are the best indicators of the degree of compaction experienced by paleosols. Clastic dikes are cracks in the soil that form vertically and are subsequently filled with contrasting material (Retallack 2001).

The degree of compaction can be calculated using the formula that Sclater and Christie (1980) developed:

$$
\mathrm{C}=\frac{-0.5}{\left[\frac{0.49}{e(D / 3.7)}-1\right]}
$$

Where $\mathrm{C}$ is the degree of compaction as a fraction, and $\mathrm{D}$ is the depth of burial in kilometers. The constant 0.5 is for solidity (the compliment of fractional porosity). This equation can be used to assess the degree of compaction in the John Day and Clarno units 
because they are geologically young enough that their burial history can be reconstructed and compared with standard compaction curves.

The burial depth of the John Day and Clarno units was $(1.5-2 \mathrm{~km})$; hence, it is unlikely that thermal maturation of organic matter occurred on these sites. Coalification and cracking of hydrocarbons at depth can produce acid reducing fluids capable of chemical alteration of deeply buried sedimentary rocks (Schmidt and McDonald, 1979). Thermal maturation usually occurs at greater burial depths than those found in the John Day and Clarno Formations. Correctly interpreting alterations of paleosol attributes from diagenetic processes is one of the most contentious arguments surrounding paleosols. Thus, unraveling the sequence of diagenetic modifications is essential when identifying paleosols.

\section{SUMMARY AND CONCLUSIONS}

While pedologists may disagree on the exact definition of a paleosol they generally agree on the criteria that distinguishes a paleosol from other stratigraphic units. These criteria include fossil root traces, soil horizons, soil structure, and mineralogy that clearly describe and distinguish paleosols as being different from other types of geologic deposits. These criteria are based on the processes that influence contemporary soil formation and include knowledge of diagentic processes that can alter paleosols that have undergone burial. Many geological features mimic paleosols, but they are found in quite different settings. Questioning the context of placement of a paleosol can lead to proper diagnosis. Lastly, paleopedologists can ask, "If it is not a paleosol, what is it?" 
Geomorphological, stratigraphical and pedolgical observations in the field combined with the use of micromorphology and mineralogy in the laboratory are essential for the identification of paleosols. Modern pedology uses soil structure, soil horizons, color and percent clay composition to describe the soil profile. When describing a paleosol, paleopedologists use molecular weathering ratios, phytolith concentrations, and ratios of Ti and $\mathrm{Zr}$ (Titanium and Zirconium) to describe paleosol properties. The differentiation of pedogenic properties resulting from the soil forming factors and relict features related earlier events require specialized investigative methods. These methods need to be refined by future paleopedologists to enhance the understanding of paleosols.

The paleosols of Central Oregon contain a substantial amount of information about the past environment. Using the paleosols as an environmental indicator, the climate can be reconstructed. Deeply weathered Ultisols, found in the Middle Eocene Clarno Formation indicate a climate that was subtropical and humid. In addition, fossil floras suggest similar vegetation in modern Mexico, Guatemala, and Honduras. The paleosols reveal a stepwise climatic cooling and drying, with a particularly dramatic climatic deterioration at the EoceneOligocene boundary.

Paleosol reconstruction is also a key to understanding the evolution of carbon dioxide concentrations throughout Earth's history and is important for the reconstruction of the links between climate and radiative forcing of the Earth's surface temperature (Pearson and Palmer, 2000). As global warming continues to be a concern, reconstruction of past climatic events will be useful to predict future trends in carbon dioxide levels; thus paleosols will continue to be important evidence of the Earth's changing environment. 


\section{REFERENCES}

Bestland, E.A. and Retallack, G.J., 1992. Reappraisal of the John Day and Clarno Formations (Eocene-Miocene) in the Painted Hills area of central Oregon. Proceedings of the Oregon Academy of Sciences, 28: 35.

Bestland, E.A., Retallack, G.J., Rice, A.E., and Mindszenty, A., 1996. Late Eocene detrital laterites in central OregonL mass balance geochemistry, depositional setting and landscape evolution: Geological Society of America Bulletin, 108: 285-302.

Bestland, E.A., 2000. Weathering flux and $\mathrm{CO} 2$ consumption determined from paleosol sequences across the Eocence-Oligocene transition. Palaeography, Palaeoclimatology, Palaeoecology. 156: 301-326.

Birkeland, P.W., 1984. Soils and Geomorphology. Oxford University Press, New York, 372 p.

Blodgett, R.H., 1988. Calcareous paleosols in the Trassic Delores Formation, southwestern Colorado. In: Paleosols and Weathering Through Geologic Time: Principles and Applications (eds. J. Reinhart \& W.R. Sigleo), Geological Society of America, Special Paper 216: 103-121.

Blodgett, R.H., Crabaugh, J.P., and McBride, E.F., 1993. The color of red beds: a geologic perspective, in Bigham, J.M., and Ciolkosx, E.L., (Eds.), Soil Color: Soil Science Society of America Special Publication, Madison, Wisconsin 31: 127-139.

Bos, R.H.G., and Sevink, J., 1975. Introduction of gradational and pedomorphic features in descriptions of soils. A discussion of the soil horizon concept with special reference to paleosols. Journal of Soil Science, 26: 223-233.

Brimhall, G.H., Lewis, C.J., Ague, J.J., Dietrich, W.E., Hampel, J., Teague, T. and Rix, P., 1988. Metal enrichment in bauxites by deposition of chemically mature eolian dust. Nature, 333: 819-824.

Bronger, A., and Catt, J.A. 1989. Paleosols: Problems of definition, recognition and interpretation. Paleopedology, 16: 1-7.

Catt, J.A., 1979. Soils and Quaternary geology in Britian. Journal of Soil Science, 30: 607642.

DeLancey, S., Genetti, C., and Rude, N., 1988. Some Sahaptian Klamath-Tsimshianic lexical sets. In W. Shipley (editor), Mounton de Gruyter, Berlin, p. 195-224. 
Dowing, K.F. and Park, L.E., 1998. Geochemistry and early diagenesis of mammal bearing concretions from the Sucker Creek Formation (Miocene) of southeastern Oregon: Palaios, 13: 199-354.

Duchaufour, P. 1982. Pedology, Pedogenesis and Classification (trans. T.R. Paton). Allen and Unwin, London.

Ford, A.B. 1987. Chemical characteristics of greywacke and paleosol of early Oligocene or older sedimentary breccia, Ross Sea, DSDP site 270. In: Geological Evolution of Antartica (eds. M.R.A. Thomson, I.A. Crame \& J.W. Thomson). Cambridge University Press, Cambridge. p.293-297

Gastaldo, R.A. 1992, Regerative growth in fossil horsetails following burial by alluvium: Historical Biology, 6: 203-219.

Ghorbani, H., Karmian, E.M., 2007. Study of Krotovina formation and their properties in soil around Isfahan. Journal of Agricultural Sciences and Natural Resources, 14(3): 1-10.

Gray, M.B., Nickelsen, R.P., 1989. Pedogenic slickenslides, indicators of strain and deformation processes in red bed sequences of the Appalachian foreland. Geology 17: $72-75$.

Hasiotis, S.T., Dubiel, D.L., 1995. Termite (Insecta, Isoptera) nest ichnofossils from the Upper Triassic Chinle Formation, Petrified Forest National Monument, Arizona. Ichnos, 2: $1-19$.

Hodson, M.E., 2002. Experiemental evidence for mobility of $\mathrm{Zr}$ and other trace elements in soils. Geochimica et Cosmochimica Acta 66: 819-828.

Hurst, V.J. (1977). Visual estimation of iron in saprolite. Geological Society of America Bulletin, 88: 174-176.

Jenny, H., 1941. Factors of Soil Formation. A System of Quantitative Pedology. McGrawHill, New York.

John Day Fossil Beds National Park website. http://www.nps.gov/joda/index.htm. Referenced on July 5, 2008.

Kimmins, J.P., 1997. Forest Ecology. $2^{\text {nd }}$ ed. Prentice-Hall, Upper Saddle River, NJ.

Leopold, E.B., Liu, G.-W., Clay-Poole, S., 1992. Low biomass vegetation in the Oligocene? In: Prothero, D.R., Berggren, W.A. (Eds.), Eocene-Oligocene Climatic and Biotic Evolution. Princeton University Press, Princeton, p. 399-420. 
MacFadden, B.J., 1988. Equidae. In: Janis, C.M., Scott, K.M., Jacobs, L.L., (Eds.), Evolution of Tertiary Mammals of North America. Terrestrial Carnivores, Ungulates and Ungulatelike Mammals, Vol. 1. Cambridge University Press, Cambridge, p.537-559.

Manchester, S.R., 1977, Wood of Tapiriria (Anacardiaceae) from the Paleogene Clarno Formation of Oregon. Review of Palaeobotany and Palynology, 23: 119-127.

Manchester, S.R., 1981. Fossil plants of the Eocene Clarno nut beds. Oregon Geology, 43: 75-81.

Muhs, D.R. Crittenden, R.C., Rosholt, J.N., Bush, C.A. and Stewart, K.C., 1987. Genesis of marine terrace soils, Barbados, West Indies: evidence from mineralogy and geochemistry. Earth Surface Processes and Landforms, 12: 605-6I8.

Munsell Color, 1975. Munsell color charts. Munsell, Baltimore, 24p.

Pearson, P.N., Palmer, M.R., 2000. Atmospheric carbon dioxide concentrations over the past 60 million years. Nature 406: 695-699.

Pickford, M.H.L., 1974. Stratigraphy and paleoecology of five late Cenozoic formations in the Kenya Rift Valley. Unpublished PhD thesis, University of London, 219 p.

Polynov, B.B., 1927. Contributions of Russian Scientists to Paleopedology. USSR Academy of Sciences, Leningrad.

Pratt, J.A., 1988. Paleoenvironment of the Eocene/Oligocene Hancock mammal quarry, upper Clarno Formation, Oregon. Unpublished MSc. thesis, Department of Geological Sciences, University of Oregon, $104 \mathrm{p}$.

Retallack, G.J., 1981a. Preliminary observations on fossil soils in the Clarno Formation (Eocene to early Oligocene) near Clarno, Oregon. Oregon Geology, 43: 147-150.

Retallack, G.J., 1983. Late Eocene and Oligocene paleosols from Badlands National Park, South Dakota. Special Paper of the Geological Society of America, 193: 82.

Retallack, G.J., 1984. Trace fossils of burrowing beetles and bees in an Oligocene paleosol, Badlands National Park, South Dakota. Journal of Paleontology, 58: 571-592.

Retallack, G.J., 1990a. Soils of the past. Unwin-Hyman, London, 520 p.

Retallack, G.J., 1991a. A field guide to mid-Tertiary paleosols and paleoclimatic changes in the high desert of central Oregon - Part 1. Oregon Geology, 53: 51-59.

Retallack, G.J., 1991b. A field guide to mid-Tertiary paleosols and paleoclimatic changes in the high desert of central Oregon - part 2. Oregon Geology, 53: 75-80. 
Retallack, G.J. 1991c. Miocene paleosols and ape habitats of Pakistan and Kenya. Oxford University Press, New York, $346 \mathrm{p}$.

Retallack, G.J., 1991d. Untangling the effects of burial alteration and ancient soil formation. Annual Reviews of Earth and Planetary Sciences, 19: 183-206.

Retallack, G.J., 1997. A Colour Guide to Paleosols. Wiley, Chichester.

Retallack, G.J., 2002. Late Oligocene and early Miocene paleosols near Kimberly, OR. Unpub. Rept. John Day Fossil Beds National Monument Contract P9325020029.

Retallack, G.J., 2004. Late Oligocene bunch grassland and early Miocene sod grassland paleosols from Central Oregon, USA. Palaeography, Palaeoclimatology, Palaeoecology 207: 203-237

Robinson, P.T., Brem, G.F., and McKee, E.H., 1984. John Day Formation of Oregon: a distal record of early Cascade volcanism. Geology, 12: 229-232.

Robinson, P.T., Walker, G.W., and McKee, E.H., 1990. Eocene, Oligocene and lower Miocene rocks of the Blue Mountains region. In G.W. Walker (editor), Geology of the Blue Mountains region of Oregon, Idaho, and Washington: Cenozoic geology of the Blue Mountains region. Professional Paper of the U.S. Geological Survey, 1437:29-61.

Ruhe, R.V., 1956. Geomorphic surfaces and the nature of soils. Soil Science, 82: 441-455.

Ruhe, R.V., 1969. Quaternary landscapes in Iowa: Ames, Iowa, Iowa State University Press, $255 \mathrm{p}$.

Russell, R.S., 1977. Plant root systems. McGraw-Hill, London, 298 p.

Schmidt, V. and McDonald, D.A., 1979. The role of secondary porosity in the course of sandstone diagenesis. In P.A. Schole and P.R Schluger (editors), Aspects of diagensis. Special Publication of the Society of Economic Paleontologists and Mineralogists, 26: 175-207.

Schaetzl, R.J., Anderson, S., 2005. Soils: Genesis and Geomorphology. Cambridge University Press, New York. 817 p.

Sclater, J.G. and Christie, J.A.F., 1980. Continental stretching: an explanation of the postmid-Cretaceous subsidence of the central North Sea Basin. Journal of Geophysical Research, 85: 3711-3739.

Stevenson, F.J., 1969. Pedohumus: accumulation and diagenesis during the Quaternary. Soil Science, 197: 470-479. 
Tarnocai, K.W.G, Valentine, O., 1989. Relic Soil Properties of the Artic and Subarctic regions of Canada. Paleopedology, 16: 9-39.

Tsai, C.-C., Chen, Z.-S., 2000. Lithological discontinuities in Ultisols along a toposequence in Taiwan. Soil Science 165: 587-596.

White, J.D.L., and Robinson, P.T. 1992. Intra-arc sedimentation in a low-lying marginal arc, Eocene Clarno Formation, central Oregon. Sedimentary Geology, 80: 89-114.

Wolfe, J.A., Forest, C.E., and Molnar, P., 1998. Paleobotanical evidence of Eocene and Oligocene paleoaltitudes in mid-latitudinal western North America. Geological Society of America Bulletin, 110: 664-678. 